\title{
İnsan Kaynaklarının Kurumsal Performansa Etkisi: Gençlik STK'ları Üzerine Ampirik Bir Araştırma
}

\author{
Emrah AYHAN (https://orcid.org/0000-0001-6152-7509), Department of Political Science and Public \\ Administration, Bingöl University, Turkey; e-mail: emrahayhan@hotmail.de \\ Murat ÖNDER (https://orcid.org/0000-0001-8300-862X), Department of Political Science and Public \\ Administration, Ankara Ylldırtm Beyazlt University, Turkey; e-mail: muratondere@ gmail.com

\section{The Influence of Human Resources on Organizational Performance: An Empirical Research on Youth CSOs}

\begin{abstract}
Civil society organizations (CSOs) have become complementary, supporting, and alternative actors in areas where public institutions and private sector organizations are insufficient or reluctant to produce social goods and services. Therefore, differentiation and failure in the organizational performance of the CSOs negatively influence sustainability, efficiency, and accessibility of goods and services that these CSOs provide. In many studies, significant relations were found between the organizational performance and the capacity of the CSOs. In parallel, the unique influence of human resources - as one of the significant components of the organizational capacity - on organizational performance is evaluated through the sample of 975 Youth CSOs randomly selected from 81 cities of Turkey in this research. Research data was gathered from a survey that was applied to representatives of these CSOs. The influence of human resources on organizational performance was tested and explained by multiple regression methods. Based on the research findings, it was seen that human resource variables of professional management, satisfaction from the management approach, satisfaction from the contribution of volunteers, number of paid workers, competence for work achievement, and organizational training influence the organizational performance of CSOs. Furthermore, policy recommendations were developed to improve the human resources and organizational performance of CSOs.
\end{abstract}

Keywords

JEL Classification Codes :
Civil Society, Youth CSOs, Organizational Performance, Human Resources, Multiple Regression.

$$
\text { C02, M10, M12, M53. }
$$

\section{Öz}

Sivil toplum kuruluşları (STK), kamu kurumları ve özel sektör kuruluşlarının toplumsal ürün ve hizmet üretmede yetersiz ya da isteksiz oldukları alanlarda önemli bir tamamlayıc1, destekleyici veya alternatif aktör haline gelmişlerdir. $\mathrm{Bu}$ nedenle, STK'ların kurumsal performanslarındaki farklılaşmalar ve başarısızlıklar, bu STK'ların sunduğu ürün ve hizmetlerin sürdürülebilirliklerini, verimliliklerini ve erişilebilirliklerini olumsuz etkilemektedir. Birçok araştırmada, STK'ların kurumsal performansları ile kurumsal kapasiteleri arasında anlamlı ilişkiler bulunmuştur. Buna paralel olarak bu çalışmada; kurumsal kapasitenin önemli bileşenlerinden olan insan kaynaklarının kurumsal performans üzerindeki özgün etkisi Türkiye'nin 81 ilinden rastgele seçilen 975 Gençlik STK örneklemi üzerinden araştırılmıştır. Araştırma verileri, bu STK'ların temsilcilerine uygulanan anket araştırmasından elde edilmiştir. İnsan kaynaklarının kurumsal performansa etkisi çoklu regresyon analizi yöntemiyle test edilmiş ve açıklanmıştır. Araştırma bulguları doğrultusunda; profesyonel yöneticilik, yönetim anlayışından duyulan memnuniyet, gönüllülerin katkılarından duyulan 
memnuniyet, maaşlı çalışan sayısı, iş tamamlayabilme yetkinliği ve kurum içi eğitimler gibi insan kaynaklarına ilişkin değişkenlerin STK'ların kurumsal performansları üzerinde etkili olduğu görülmüştür. Ayrıca, STK'ların insan kaynaklarının ve kurumsal performanslarının iyileştirilmesine yönelik politika önerileri geliştirilmiştir.

Anahtar Sözcükler $\quad$ : Sivil Toplum, Gençlik STK'ları, Kurumsal Performans, İnsan Kaynakları, Çoklu Regresyon.

\section{Giriş}

1980’lerden sonra yaşanan siyasal, sosyolojik ve ekonomik gelişmelere paralel olarak önemini artıran sivil toplum, kamu sektörü ile özel sektörden sonra üçüncü bir sektör olarak ortaya çıkmıştır. Özellikle, küreselleşme sonucunda ulus-devletin egemenliğinin aşınması ve ülkeler arası sınırların kalkması üzerine birçok tartışma ortaya çıkmıştır (Önder, 2019). Salamon vd.'ye (1999: 4) göre bu gelişmelerin en önemlileri şunlardır; a) dünyanın farklı bölgelerinde refah devletinin, sosyalist devletin ve devlet destekli kalkınmanın krize girmesi, b) insan sağlığı ve güvenliği nedeniyle toplumsal ve çevresel endişelerin artması, son olarak da c) devletlerin piyasa odaklı ekonomi politikalarının başarısız olmasıdır. Ayrıca, 1980’lerden sonra Türkiye ve dünyadaki kamu yönetimi anlayışı; etkinlik, etkililik ve verimlilik gibi özel sektör değerlerini öngören Yeni Kamu İşletmeciliği yaklaşımından etkilenmiştir (Göçoğlu vd., 2019). Ancak zamanla aşırı piyasa odaklı olması ve vatandaşları müşteri gibi değerlendirmesi gibi nedenlerle eleştirilmeye başlanan bu yaklaşıma karşı yeni arayışlara girişilmesi de sivil toplum sektörünün güçlenmesine katkı sağlamıştır (Ayhan \& Önder, 2017).

1970’lerden itibaren, kamu kurumlarının ve özel sektör kuruluşlarının vatandaşlara kamusal ürün ve hizmet sunmada neden başarısız olduklarını açıklayan yeni teoriler geliştirilmiştir. Örneğin, Weisbrod (1975) kamu kurumlarının başarısızlığını 'devlet başarısızlığı' (government failure) olarak adlanmıştır. Hükümetlerin bir sonraki seçimlerde tekrar seçilebilmek için toplumdaki çoğunluğu oluşturan ortalama seçmenlerin (median voter) isteklerine göre hareket ettiğini ancak; yaşam tarzı, ırk, dil, kültür ve inanç gibi farklılıkların yoğun olduğu bölgelerdeki çeşitlenen arzu ve isteklerin karşılanmasında başarısız oldukları ileri sürülmektedir (Levitt, 1973; Weisbrod, 1975). Bu noktada, Sivil Toplum Kuruluşları (STK'lar) az sayıda olan kişi ya da grupların arzu ve isteklerini karşılamada daha iyi bir alternatif olarak ortaya çıkmaktadırlar (Garton, 2009: 47; James \& Rose-Ackerman, 1986: 60). Kamu kurumlarının yapmadığı veya yapamadığı bazı kamusal ürün ve hizmetleri sunması beklenen özel sektör kuruluşları da 'piyasa başarısızlığı' (market failure) nedeniyle bu konuda yetersiz kalmaktadırlar. Bunun ilk nedeni bu ürün ve hizmetlerin (toplu taşıma ve kamusal altyapı vb.) kaç kişinin kullandığına bakılmaksızın tüm vatandaşların erişimine açık olmasıdır (non-rivalry) (Cooter \& Ulen, 2000: 15). İkinci neden ise, bazı vatandaşların (vergi ödemeyen vb.) kamu ürün ve hizmetlerinden (ulusal savunma sistemleri, kamusal yol ve parklar vb.) faydalanmasının kısıtlanmasının imkânsız ya da çok masraflı olmasıdır (Steinberg, 2006: 119). Son olarak, isteğe bağlı olan ürün ve hizmetler için bazı vatandaşlar ödeme yaparken ya da kendi istekleriyle faaliyette bulunurken bazı 
Ayhan, E. \& M. Önder (2021), "İnsan Kaynaklarının Kurumsal Performansa Etkisi:

Gençlik STK'ları Üzerine Ampirik Bir Araștırma”, Sosyoekonomi, 29(48), 443-472.

vatandaşların 'beleşçi' (free-rider) gibi davranarak ödeme yapmaması ya da faaliyette bulunmaması nedeniyle diğerlerinin de bundan vazgeçmesidir (Olson, 1971: 14-16). Devlet bu sorunun üstesinden zorunlu vergiler ile gelse de özel kuruluşların böyle bir imkânı bulunmamaktadır (Ayhan, 2019). Bu nedenle kâr amacı güden özel sektör kuruluşları kamusal ürün ve hizmet sunmada kâr edemedikleri için isteksiz davranmaktadırlar. Buna karşın kâr amacı gütmeyen, kamu yararını, sosyal hizmeti ve kaliteyi esas alan STK'lar, bu tarz ürün ve hizmet üretmede daha başarılı ve güvenilir alternatiftirler (Fowler, 2000; Gronbjerg, 1993; Hackler \& Saxton, 2007; Hansmann, 1987; Mitchell, 2014).

Kamu kurumları ile özel sektör kuruluşlarının kamusal ürün ve hizmet sunmada yetersiz kalmaları, isteksiz olmaları ya da başarısız olmaları nedeniyle STK'lar önemli bir destekleyici, tamamlayıcı ve alternatif aktör olarak (Önder, 2006; Önder, 2011) ortaya çıktıkları için kamu-özel-sivil toplum sektörlerinin ortaklığı gündeme gelmiştir (Ayhan \& Önder, 2017: 41). Bu üç boyutlu ortaklık genel olarak bu aktörler arasında karmaşık bir sistem, ilişkiler ağı ve karşılıklı bir etkileşim öngören 'yönetişim' yaklaşımına dayanmaktadır (Özer, 2006: 67; Yıldırım \& Önder, 2019). Ancak, son zamanlardaki artan önemlerine rağmen ihtiyaç sahiplerine kamusal ürün ve hizmet sunan STK'ların kapasitelerinin yeterli olup olmadığı da önemli bir tartışma konusudur. Örneğin, yetersiz finansal kapasiteye sahip olan STK'lar, faaliyetlerini ve yeni programlarını zorlukla sürdürebilmektedirler (Besel vd., 2011; Calabrese, 2013; Salamon \& Geller, 2007; SontagPadilla vd., 2012; Weerawardena vd., 2010; Önder vd, 2019). Çünkü kurum ya da kuruluşların hizmet sundukları kişi ya da gruplar üzerinde nasıl bir etkide bulundukları kurumsal kapasite tarafindan belirlenir (Despard, 2016: 2). Ayrica, kurumsal kapasite ile kurumsal performans arasında doğrudan bir ilişki olduğu da önceki araştırmalar tarafından ortaya konulmuş (Despard, 2016: 2, De Vita \& Fleming, 2001; Light, 2004) ve hangi kapasite faktörlerinin kurumsal performans üzerinde etkili olduğu açıklanmıştır (Christensen \& Gazley, 2008; Eisinger, 2002; Honadle, 1981).

Bir kuruluştaki mevcut çalışanların niteliği; finansal kaynaklar ve kurumsal fonksiyonlar gibi bir kurumun misyonunu yerine getirebilmesi ve etkili ürün ve hizmet sunabilmesi için önem arz etmektedir (Doherty vd., 2013; Eisinger, 2002; Millesen vd., 2010). Hem özel sektörde hem de kamu kurumlarında gerek bireysel ve gerekse kurumsal performans giderek daha da önemle gündemde kalmaya devam etmekte ve performans denetimleri yapılmaktadır. Türk kamu kurumlarının da performansları yeni Sayıştay kanunuyla birlikte denetlenmeye başlanmıştır (Önder \& Meydanlı, 2019). Ancak ülkemizde halen STK'ların performansı yeterince ele alınmamaktadır. $\mathrm{Bu}$ nedenle bu çalışmada, "kurumsal kapasitenin önemli bileşenlerinden biri olan insan kaynaklarının kurumsal performansa etkisi nedir?” genel araştırma soruna cevap aranacaktır. Önceki araştırmalara ve kuramlara dayanılarak oluşturulan hipotezlerin test edilebilmesi için geliştirilen modellerde kullanılan birincil veriler, Türkiye'nin 81 ilinden 975 Gençlik STK Temsilcisine (başkan, yönetici, gençlik sorumlusu, gönüllü lider vb.) yarı yapılandırılmış ayrıntılı bir anket araştırması uygulanarak elde edilmiştir. Bu STK'lar; gençlik, spor ve eğitim alanlarında faaliyet gösteren Gençlik STK'ları arasından rastgele seçilmiştir. Betimleyici istatistiksel analiz ve En Küçük Kareler (EKK) regresyon analiz yöntemi (Ordinary Least 
Ayhan, E. \& M. Önder (2021), "İnsan Kaynaklarının Kurumsal Performansa Etkisi:

Gençlik STK'ları Üzerine Ampirik Bir Araştırma”, Sosyoekonomi, 29(48), 443-472.

Squares - $O L S$ ) regresyon yöntemleri ile farklı değişkenler arasındaki ilişkiler test edilmiş ve bulgular tartışılıp değerlendirilmiştir. Böylelikle, STK'ların insan kaynakları ile kurumsal performans arasındaki ilişkileri açıklanmış ve sorunlar irdelenmiştir. Analiz sonuçları kapsamında; STK yöneticilerine, araştırmacılara, kamu politikaları belirleyenlere ve uygulayanlara, STK'ları destekleyen kamu/kamu-dışı kurum ve kuruluşlarına yönelik olarak STK'ların kurumsal performanslarının geliştirilmesi için politika önerileri sunulmuştur. Ayrıca, bu çalışmanın kısıtlılıkları göz önünde bulundurularak gelecekteki çalışmalara yönelik tavsiyelerde bulunulmuştur.

\section{STK'ların Kurumsal Performansları}

Literatürde, STK'ların kurumsal kapasitelerine ve performanslarına yönelik birçok teorik ve uygulamalı çalışma bulunmaktadır. Çoğu araştırmaya göre, bir STK'nın kurumsal kapasitesi; sahip olduğu finansal kaynaklar, çalışanların yetenekleri ve kurumsal fonksiyonlardan oluşmaktadır. Çünkü bu faktörler, STK'ların verimli bir şekilde kurumsal misyonlarını yerine getirilmelerini ve kamusal ürün ve hizmetler sunmalarını etkilemektedir (Doherty vd., 2013; Eisinger, 2002; Millesen vd., 2010). Örneğin, stratejik yönetim teorileri kuruluşların iç ve diş çevrelerindeki değişimlere uyum sağlayabilmek ve başarılı olmak için stratejik çözümler belirlemeleri ve kurumsal kapasitelerini güçlendirmeleri gerektiğini belirtirler (Barney \& Hesterly, 2012; Hill \& Jones, 2008; Oster, 1995). Benzer bir şekilde, kaynak bağımlılığı teorisine göre kuruluşlar sürdürülebilirlik ve büyüme için mücadele ederler (Froelich, 1999; Hillman vd., 2009; Pfeffer \& Salancik, 1978). Bu bağlamda önceki kuram ve araştırmalar, kuruluşların performanslarını, yönetsel ve örgütsel kapasitelerini geliştirmek için insan kaynaklarının yetkinliğini artırma; finansal kapasitelerini artırmak için ise kaynak oluşturma ve etkin kaynak kullanımı gibi konular üzerine odaklanmaktadır.

Gönüllü bağışlar, aidatlar ve proje gelirlerine bağımlı olan STK'lar, özel sektör kuruluşlarına göre tahmin edilmesi zor olan dışsal belirsizliklerle ve kaynak krizlerine daha fazla maruz kalmaktadırlar (Goel \& Kumar, 2005; Onder, 2012). Özellikle, son y1llarda STK'lar hesap verebilirlik ve performans konularında hem toplumdan hem de STK'lara mali kaynak sağlayan kurum ve kuruluşlardan baskı görmektedirler (LeRoux \& Wright, 2010). Çünkü STK'lar gün geçtikçe daha da büyümekte, profesyonelleşmekte, finansal kaynaklarını artırmakta ve faaliyet alanlarını genişletmektedirler. Kamu yararı gözetip kâr amacı gütmeden toplumsal ürün ve hizmet üretseler de diğer kurum ve kuruluşlar gibi faaliyetleri ve performansları izlendiği için STK'lar da saydamlık, etkililik, verimlilik ve hesap verebilirlik gibi kurumsal yetkinlik kriterleriyle yüzleşmektedirler. Türkiye'de sivil toplum açısından yönetsel yetkinlik ve performans konuları yeteri kadar gündeme gelmese de batılı ülkelerde çoğu STK performans ölçüm ve değerlendirme yöntemlerini kullanmakta ve kamusal hesap verebilirliklerini sağlamaya çalışmaktadırlar (Carman, 2007; Morley vd., 2001). Örneğin, ABD gibi bazı ülkelerde performans yönetimi özellikle vurgulanmakta ve kamu kurumlarıyla işbirliği yapmak isteyen STK'ların çoğu kamu kurumları tarafından sağlanan mali kaynaklardan faydalanabilmek için performans değerlendirilmesine tabi tutulmaktadırlar (Frederickson \& Frederickson, 2007; LeRoux \& Wright, 2010). Bu nedenle STK'ların, performans ölçümünü esas alarak kurumsal performanslarını ve hesap 
verebilirliklerini artıracak politikalar izlemeleri beklenir. Çünkü STK yöneticileri, performans ölçümü sistemlerinin uygulanmasıyla elde edilecek olan verileri kullanarak daha etkin bir yönetim sağlayabilecek ve daha doğru stratejik kararlar verebileceklerdir (Moynihan, 2005; Wholey, 1999). Nitelikli veriye dayalı performans bilgisi doğrultusunda karar veren yöneticiler, performansın artırılması için kuruluşun sahip olduğu finansal kaynakları, fiziki ve teknolojik altyapıyı ve insan kaynaklarını daha etkin ve verimli bir şekilde dağıtabilirler. Bunun sonucunda ise daha çok ihtiyaç sahibine erişilebilir, sürdürülebilir, etkin, ekonomik ve verimli kamusal ürün ve hizmetler sunabilirler.

Kurumsal performansın en temel göstergeleri verimlilik ve etkililiktir. Etkililik kurumun amaçlarına ne derece ulaştığını açıklarken verimlilik ise, minimum kaynaklarla (personel, fiziki ve teknolojik altyapı, finansal kaynaklar vb.) maksimum çıktıyı (ürün ve hizmetler) elde etmeye odaklanır (Saruhan \& Yıldız, 2017: 363). Bu nedenle, STK yöneticileri, özel sektör kuruluşlarında olduğu gibi belli aralıklarla performans değerlendirmesi yaparak misyonlarını yeri getirmede ve hedeflerine ulaşmada ne kadar etkili ve verimli olduklarını öğrenebilirler (Coşkun, 2006: 105). Böylece, olumlu ve olumsuz yanlar ile geliştirilmesi gereken noktalar stratejik olarak da belirlenmiş olacaktır. Ancak, tüm STK'ları kapsayan standart performans ölçütleri belirlemek kolay değildir (Herman \& Renz, 2008). Buna karşın, literatürdeki bazı temel çalışmalardan performans ölçütlerine yönelik genel bir çerçeve çizilebilir. Fine \& Snyder'e (1999: 24) göre performans ölçümü; hizmet sunumu metotlarının etkililik ve verimliliğini belirleyen performans göstergelerinin seçilmelerini, tanımlanmalarını ve uygulanmalarını içermektedir (Özgür \& Aydın, 2020). Aynı şekilde, Smith (1988: 24) de performans ölçütlerini verimlilik ve etkililik üzerinden tanımlama yoluna gitmiştir. Verimlilik, kaynaklarla bu kaynakların kullanımından elde edilen sonuçlar arasındaki ilişkiyi ölçer (Bilgin, 2015; Özer, 2009). Diğer taraftan etkililik ise bir hizmetin nasıl sunulduğunun ya da bir faaliyetin daha önceden belirlenen hedefleri sağlayıp sağlamadığının ölçülmesidir. Bundan farklı olarak, Morley vd. (2001: 5) etkinliği bir kuruluşun hizmetlerinin kalitesi ya da belirli bir arzulanan sonuç anlamına gelen çıktılar üzerinden tanımlamaktadır. Örneğin, Carman'ın (2007) New York'taki toplum temelli STK'lara yönelik uyguladığı anket ve mülakat sonuçlarına göre araştırmaya katılan 178 STK'nın \%60'ı çıktılara ve sonuçlara dair veri topladığını belirtirken, bu STK'ların \%97'si faaliyet harcamaları ve diğer harcamalara dair veri topladıklarını belirtmişlerdir.

Sonuç olarak, STK'lar etkililik, verimlilik, hesap verebilirlik ve daha fazla ihtiyaç sahibine ulaşabilmek açısından kurumsal performanslarını artırmak için gereken stratejileri izlerler. Her ne kadar insan kaynaklarıyla birlikte STK'ların kurumsal performanslarını etkileyen dış paydaş ilişkileri, finansal kaynaklar, fiziki ve teknolojik altyapı gibi önemli faktörler olsa da bu çalışma, insan kaynaklarının niteliğinin kurumsal performans üzerinde nasıl bir etkiye sahip olduğuna odaklandığı için bir sonraki bölümde STK'ların insan kaynaklarına dair yapılan teorik ve ampirik araştırmalara dayanarak nedensel ilişkileri belirten hipotezler geliştirilmiştir. 
Ayhan, E. \& M. Önder (2021), "İnsan Kaynaklarının Kurumsal Performansa Etkisi:

Gençlik STK'ları Üzerine Ampirik Bir Araştırma”, Sosyoekonomi, 29(48), 443-472.

\section{STK'lardaki İnsan Kaynakları}

Giderek artan ve karmaşıklaşan ihtiyaçları karşılayabilmek için STK'larda, gönüllü çalışanların yanı sıra profesyonel yöneticilerin ve çalışanların istihdamına yönelik talep artmaktadır. Örneğin, profesyonel çalışanlar amatör ruh ile hareket eden gönüllü çalışanların baş edemediği sorunlara yönelik daha etkili çözüm sunabilirler. Diğer taraftan, profesyonel STK yöneticilerinin örgütü etkin bir şekilde yönetme görevlerine ek olarak kaynak oluşturma ile yeni üye/gönüllü bulmak gibi önemli görevleri de vardır. Çünkü, kurumun sürekliliği ve misyonun yerine getirilmesi için STK'ların sahip oldukları finansal ve insan kaynakların çeşitlendirilmesi önem arz etmektedir (Coşkun, 2006: 104). STK'ların kurumsal kapasitelerinin önemli bir parçası olan insan kaynaklarının niteliği üzerine birçok çalışma bulunmaktadır (Tuckman \& Chang, 1991; Sontag-Padilla, 2012). STK'lar kamu ve özel sektör kuruluşlarından farklı olarak gönüllü çalışanlar grubu ile ayrı bir insan kaynakları grubuna sahiptir. Bundan dolayı bu kısımda; yöneticiler, gönüllüler ve diğer yarı ve tam zamanlı çalışanlar olmak üzere STK'ların insan kaynakları unsurlarını oluşturan üç ana grubun yetkinliklerine yönelik teorik ve ampirik çalışmalar incelenmiş ve hipotezler geliştirilmiştir.

\subsection{Yönetim ve Yöneticilerin Yetkinlikleri}

Özel sektör kuruluşlarında ve kamu kurumlarında, stratejik liderlik ile ilgili birçok çalışma bulunmasına rağmen (Önder, 1997; Boal \& Hooijberg, 2000; Carter \& Greer, 2013; Dinwoodie vd., 2014; Lear, 2012; Öktem \& Çiftçi, 2019) sivil toplum alanında STK'lara yönelik yapılan çalışmaların sayısı görece daha azdır (Bibu \& Lisetchi, 2011; Bilgin vd., 2017). Bu durumun en önemli nedenleri arasında, STK'ların özel sektör kuruluşlarından farklı olarak kâr amacı gütmemeleri ve diğer kuruluşlarla maddi anlamda yoğun bir rekabete girişmemeleri sayılabilir. Bu anlamda, kamu yararı güden STK'lar kâr amacı güden özel sektör kuruluşlarına göre daha güvenilirdirler (Hansmann, 1987). Ayrıca STK'ların rekabet ettikleri alanlar ise genel olarak kaynak oluşturma, birikim, hizmet kalitesi, insanların ihtiyaçlarının karşılanması ve bilinirlik gibi alanlardır (Tuckman, 1998: 26-28).

Liderlik, bir liderin diğer grup üyelerini belli bir amacın gerçekleştirilmesi için yönlendirdiği bir süreç olarak tanımlanabilir. Burns’a (1978) göre ise bir lider kendi takımı için yüksek düzeyde ahlak, motivasyon ve performans oluşturan kişidir. Ancak, bir kuruluştaki liderlik sadece bir kişi olarak anlaşılmamalıdır. Çünkü liderlik olgusu üst düzey yöneticileri (top management team), kuruluş içindeki etkili grupları (dominant coalitions) (Boal \& Hooijberg, 2000), idarecileri (board of directors), birim yöneticilerini (department general managers) (Shrivastava \& Nachman, 1989) içermektedir. Bu nedenle, iyi bir liderin, kurumsal performansın artırılması ve hedeflere ulaşılması için gereken stratejilere, yeteneklere ve özelliklere sahip olması beklenmektedir. Ayrıca, bu liderlerin klasik yönetim anlayışındaki özellikler yerine günümüzdeki gerekliliklere uygun özelliklere sahip olmaları gerekmektedir (Öktem \& Çiftçi, 2019). Yöneticilerin yetkinlikleri; STK'lardaki profesyonel yöneticilik, yöneticilerin STK tecrübeleri ve eğitim düzeyleri, yönetici devir sıklığı, yönetim 
anlayışından ve uygulamalarından duyulan memnuniyet gibi temel kavram ve konular üzerinden açıklanmıştır.

\section{Profesyonel Yöneticilik}

Yönetimde profesyonelleşmenin önemli bir boyutu profesyonel yönetici istihdamıdır. Gönüllülüğün başarısızlığı teorisine göre uzmanlık gerektiren alanlarda gönüllülerin amatör bir şekilde çalışması STK'lar açısından sorunlara yol açmaktadır (Salamon, 1987). Bu nedenle, STK'lardaki gönüllü çalışanların profesyonel, maaşlı ve tam zamanlı yöneticilerle desteklenmesi gerekir. Çünkü maaşlı, tam zamanlı ve profesyonel yöneticiler tüm yeteneklerini, sadece müsait olduklarında değil tam olarak tüm mesai ve motivasyonlarını bulundukları STK'ların performanslarını yükseltmek için kullanacaklardır.

\section{Hipotez 1: Profesyonel yöneticiye sahip STK'ların daha yüksek kurumsal performansa sahip} olması beklenir.

\section{Yöneticilerin STK Tecrübeleri}

Önceki araştırmalarda tecrübeli çalışanların kurumun performansına ve değerine katkı sağladıkları belirtilmektedir (Judge vd., 1995; Nafukho vd., 2004). Örneğin, McDaniel vd.'ye (1988) göre çalışanların kurumdaki tecrübeleri arttıkça bu çalışanlar daha yüksek performans gösterirler. Buna karşın, aynı kurumda çok fazla tecrübeye ve çalışma süresine sahip yöneticilerinin bulunduğu STK'larda ise olumsuz gelişmelerin ve sorunların daha çok dışsal sebeplerden kaynaklandığı düşünülür (Schwenk, 1993). Bu durumda, kuruluştan kaynaklanan içsel sorunlar göz ardı edileceği için sorunların çözümüne yönelik alınan kararlar etkisiz kalacak ve kurumsal performans düşecektir. Yine de literatürdeki çoğu araştırmaya göre, kurumsal performans ile yöneticilerin tecrübeleri arasında olumlu bir ilişki bulunmaktadır (Chi vd., 2009; Goll \& Rasheed, 2005; Joshi vd., 2011). Çünkü insan sermayesi teorisine göre çalışanlar mesleki bilgilerini, becerilerini, tecrübelerini ve yeteneklerini artırdıklarında insan sermayesi de artmaktadır (Myers vd., 2004; Wayne vd., 1999). Bu nedenle, nitelikli yöneticilerin kurumsal görevlerini ve sorumluluklarını yerine getirirken daha yüksek performans gösterecekleri düşünülmektedir (Humphrey vd., 2009; Steffens vd., 2014). STK'ların yönetiminde özel sektör kuruluşları ve kamu kurumlarından farklı olarak gönüllüler ve mali kaynak sağlayıcıların özgün bir şekilde yönetişimi de ön plana çıkmaktadır. Bundan dolayı, STK yöneticilerinde, genel tecrübe yanında yöneticilerin STK tecrübeleri de ayrı bir önem kazanmaktadır. Bu bilgiler ışığında, yöneticilerin gönüllü ya da ücretli çalışan olarak edindikleri STK tecrübesinin, STK'lardaki insan kaynaklarının niteliği açısından önemli bir gösterge olduğu söylenebilir.

Hipotez 2: Yöneticilerin sivil toplum tecrübesi arttıkça kurumsal performansın da artması beklenir. 


\section{Yöneticilerin Eğitim Düzeyleri}

STK yöneticilerinin kendilerine verilen işleri başarıyla yapabilmeleri için yeterlilik ve liyakat kavramları önem arz etmektedir. Bu nedenle, herhangi bir görev için çalışan istihdam ederken kişinin gerekli yeterlilik ve liyakate sahip olup olmadığına bakılır (Koç, 2016: 69). Bu kapsamda, eğitim düzeyi aynı tecrübe gibi sürekli gelişmelere uyum sağlama kapasitesi sağladığı için insan sermayesinin önemli bir göstergesi olarak insan kaynaklarının performansını ve niteliğini artırma potansiyeline sahiptir (Önder, 2006). Örneğin, Feigenbaum'un (1980) bulgularına göre eğitim, gelir ve yaş bakımından çeşitliliğinin yüksek olduğu yerlerde sivil toplum daha aktiftir. Diğer taraftan, Ben-Ner \& Van Hoomissen'e (2007) göre daha iyi gelir ve eğitim düzeyine sahip insanlar nitelik ve nicelik bakımından daha iyi ürün ve hizmetleri tercih ederler. Son olarak Önder'e (2011) göre, STK'lardaki yöneticilerin eğitim düzeyi ile STK'ların büyüklüğü arasında pozitif ilişki gözlenmiştir.

\section{Hipotez 3: Yöneticilerin eğitim düzeyleri arttıkça kurumsal performansın da artması beklenir.}

\section{Yönetici Devrinin Sıklı̆̆ı}

Bir kuruluşta çalışan yöneticiler, çok fazla tecrübeye sahiplerse ve bulundukları kurumda uzun yıllardan beri çalışıyorlarsa bu yöneticilerin zamanla motivasyonları azalmakta ve STK'larda ortaya çıkan olumsuz sonuçların nedenlerini dışsal sebeplere bağlama eğilimine girilmekte, STK'ların mevcut yapılarından ya da yönetimlerinden kaynaklanabileceğini göz ardı edebilmektedirler (Schwenk, 1993). Böyle bir anlayış ise çevresel etkilere duyarlılığı azaltmakta, yenilikleri engellemekte ve örgütsel entropiye neden olmaktadır. Bu da STK'lardaki yeni sorunların çözümüne, performansın artırılmasına ve etkili kararlar alınabilmesine engel olabilmektedir (Chi vd., 2009; Goll \& Rasheed, 2005; Joshi vd., 2011). Örneğin, Çaha \& Çaylak (2013) başkanlık değişimini STK'lardaki demokratik kültür, kişilerden bağımsız kurumsal yapı ve çoğulculuk üzerinden incelemektedirler. Bunun için Türkiye'deki TRA2 (Ağrı, Ardahan, Iğdır ve Kars) istatistikî bölgesinde faaliyet gösteren 320 tane STK'ya yönelik yaptıkları araştırmanın sonuçlarına göre: STK'larda demokratik ve çoğulcu bir seçimle başkanlık değişimi olmadığı ve başkanların uzun süre görevlerine devam ettikleri görülmüştür. Başkanların kuruluşla özdeşleşmesi sonucunda STK'lardaki değişim ve gelişim bu kişilerin bireysel çabalarına bağlıdır; faaliyetler takım çalışmasından ziyade bireysel çaba ve amatör ruh ile yürütülmektedir (Çaha vd., 2018; Çaha \& Çaylak, 2013). Onun için yöneticilerin belirli aralıklarla değişmesi kuruluşa yenilik, dinamizm, açıklık, motivasyon, etkin mali saydamlık ve yönetim sağlar (Connolly, 2018). Buna karşın, kurumsal liderlerin politik ve ideolojik kaygılarla çok sık değişmesi de faaliyetlerin, kurumsal hafızanın ve kurumsal kültürün sürdürülebilirliği açısından sorunlara neden olabilir (Doherty vd., 2019) ve bu durum kurumsal performansı zayıflatabilir. Özellikle Türkiye gibi lidere bağımlı kurumsal kültürün olduğu yerlerde bu durum daha fazla önem arz edebilmektedir. 
Ayhan, E. \& M. Önder (2021), "İnsan Kaynaklarının Kurumsal Performansa Etkisi:

Gençlik STK'ları Üzerine Ampirik Bir Araştırma”, Sosyoekonomi, 29(48), 443-472.

Hipotez 4: Yönetici devrinin sıklı̆̆ arttıkça STK'ların kurumsal performanslarının azalması beklenir.

\section{Yönetim Anlayışından Duyulan Memnuniyet}

STK'lardaki yöneticilerin yetkinlikleri ile ilgili bir diğer husus, kurumsal yönetim anlayışından duyulan memnuniyettir. Çünkü mevcut kurumsal yönetim ne kadar etkili olursa kurumsal performans da o kadar artacaktır. Örneğin, Tiyek’e (2013: 121) göre kuruluşların en önemli beşerî sermayesi olan çalışanların performanslarının artırılması bu çalışanların bulundukları çalışma ortamının durumu, maddi ve manevi ihtiyaçlarının karşılanması gibi bazı önemli faktörlere bağlıdır. Diğer taraftan, Koçel'e (2001: 376) göre ise çalışanların memnuniyetinin sağlanamaması sonucunda bu çalışanların motivasyonları düşeceği için verimlilikleri azalacak, personel devir oranı artacak ve kuruluşun işleyişinde sıkıntılar ortaya çıkacaktır. Çalışanların daha etkili ve verimli çalışmalarını sağlayacak olan gerekli koşulları oluşturacak kişiler yöneticiler olduğu için bu liderlerin özellikleri önem arz etmektedir. Literatürde; kurumsal performansın artırılmasına yönelik dönüştürücü liderlik (transformational leadership), etik liderlik (ethic leadership), hizmetkâr liderlik (servant leadership) ve etkileşimli liderlik (transactional leadership) gibi liderlik türleri öne çıkmaktadır. Bunlar arasında görece daha güncel olan dönüştürücü liderlik ilk olarak Burns (1978) tarafından dile getirilmiştir. Dönüştürücü bir lider sadece kurumsal vizyonu değil aynı zamanda STK çalışanlarının performanslarını da göz önünde bulundurarak bu çalışanları kendi karizmasıyla etkilemekte, her bir çalışana bireysel olarak vakit ayırmakta, çalışanları güçlükler karşısında motive etmekte, onların stresini azaltmakta ve çalışanlara rol modellik yapmaktadırlar (Ekmekçi vd., 2018: 592; Mahalinga Shiva \& Suar, 2012: 687). Diğer taraftan, etkileşimli lider ise liderlerle diğer çalışanlar arasındaki bir değiş tokuşu içermektedir (Bass \& Avolio, 1995). Yani etkileşimli liderler, çalışanlara istediklerini verip bunun karşılığında kendi istediklerini elde etmektedirler (Kuhnert \& Lewis, 1987). Genel olarak tüm liderlik türlerinde çalışanların liderlerden ve kurumsal yönetim anlayışlarından duydukları memnuniyet kurumsal performansa olumlu etki etmektedir.

Hipotez 5: STK çalışanlarının kurumsal yönetim anlayışından duydukları memnuniyetin kurumsal performansi artırması beklenir.

\subsection{Gönüllüler}

Herhangi bir maddi beklenti içinde olmadan gönüllü faaliyetlerini yürüten gönüllüler, STK'lardaki insan sermayesinin temelini oluştururlar. $\mathrm{Bu}$ gönüllüler genelde sosyal sorumluluk, sosyalleşme, aidiyet hissi, entelektüel ve kişisel gelişim, topluma yarar sağlama ve ihtiyacı olanlara yardım etme gibi manevi güdülerle hareket ederler (Güngör, 2016). Gönüllülüğe dayandığı için sivil toplum aynı zamanda gönüllü sektör olarak da adlandırılır. Çünkü STK'lar gönüllüler sayesinde etkili ve verimli bir şekilde ihtiyacı olanlara yönelik kamusal ürün ve hizmetler sunmaktadırlar. Günümüzde, sivil toplumun öneminin artması sonucunda karmaşık ve hassas sosyal sorunlara yönelik hizmet sunmak isteyen STK'lar daha profesyonel ve donanımlı insan kaynaklarına ihtiyaç duymaktadırlar. Ancak, finansal 
kapasitesi düşük olan çoğu STK bu ihtiyaçlarını nitelikli gönüllü çalışanlar ile karşılamaya çalışmaktadır.

Salamon (1987), STK'ların ortaya çıkış nedenlerini ve nasıl başarısız olabileceklerini açıklama amacıyla gönüllük üzerinden yeni bir teori geliştirmiştir. 'Gönüllülüğün başarısızlığı' (voluntary failure) adlı bu teoriye göre STK'ların varlığı devletin başarısızlığıyla açıklanamaz. Bunun yerine, STK'ların neden var oldukları, insanların sosyal görev bilinçleri ve toplu şekilde hareket etme dürtülerinden kaynaklanan gönüllü faaliyetler ile açıklanmaktadır (Anheier, 2005: 130). Buna ek olarak, gönüllülügüun başarısızlığ1 teorisine göre STK'ların da başarısız olmalarına neden olan bazı faktörler bulunmaktadır. Bunların en başında gelen şey uzmanlık gerektiren sorunlara amatör yaklaşımla çözüm aranması anlamına gelen 'amatör hayırseverlik' (philanthropic amateurism) faktörüdür (Salamon, 1987: 42). STK'ların çoğunun faaliyetlerini gönüllüler üzerinden yürüttükleri düşünüldüğünde bu amatörlüğün hem olumlu hem de olumsuz gelişmelere yol açabileceği söylenebilir. Örneğin, amatörlük ruhu girişimciliği ve sivil katılımı destekleyebilir. Diğer taraftan, finansal kapasite yetersizliği ve finansal kırılganlık nedeniyle birçok STK, uzmanlık gerektiren alanlar için gereken profesyonel, tam zamanlı ve maaşlı çalışanlar istihdam edememektedir (Önder \& Ayhan, 2020). Amatörlük nedeniyle STK'lar tarafindan sunulan ürün ve hizmetlerin kalitesi de düşebilmektedir (Güngör, 2016).

Gönüllü yetersizliği veya amatör gönüllülük nedeniyle başarısızlığa uğramamak için kurumsallaşmasını artırmak isteyen STK'lar profesyonel gönüllü yönetimine gereksinim duyarlar. Bunun için, STK'lardaki gönüllü çalışan sayıları şimdiki ve gelecekteki faaliyetlerin yürütülebilmesi için yeterli düzeyde olmalıdır. Örneğin, STK'ların sahip oldukları üye sayıları STK'lar için potansiyel gönüllü çalışan havuzu anlamına gelmektedir. Normal şartlar altında finansal yetersizlik nedeniyle istihdam edilemeyen maaşlı çalışanların yerine bu havuzdan gönüllü çalışanlar istihdam edilerek kurumsal ihtiyaçlar karşılanabilmektedir (Akatay, 2008). Bu nedenle, üye sayısı fazla olan STK'larda farklı bilgi ve becerilere sahip gönüllüler bulmak daha kolay olacağı için insan kaynakları ihtiyacı daha kolay karşılanacak ve böylece kurumsal performans artacaktır. Sonuç olarak, gönüllü çalışan sayısı yüksek olan STK'ların daha başarılı olmaları beklenmektedir (Güngör, 2016).

\section{Hipotez 6: Gönüllüğ̈̈n daha fazla olduğu STK’larda kurumsal performansın da yüksek olması beklenir.}

Gönüllü sayısının yanında gönüllü çalışanların etkinlikleri, becerileri, girişimci yönleri, toplumsal sorunlara yönelik farkındalıkları, sorumluluk bilinçleri ve tutarlılıkları gibi nitelikleri de kurumsal performansı etkiler. Bu niteliklere sahip gönüllülerin STK'lara daha fazla katkı sağlamaları olağan bir durumdur. Bunun için kuruluştaki her görev için uygun gönüllülerin belirlenmesi, gerekli bilgilendirmelerin ve eğitimlerin yapılması, görev tanımlarının iyi yapılması, ödül mekanizmaları aracılığıyla gönüllülerin motivasyonlarının yüksek tutulmasına ihtiyaç duyulmaktadır. Gönüllülerini profesyonel olarak yöneten STK'larda bu konularda gönüllülerden ve niteliklerinden duyulan memnuniyet düzeyinin daha yüksek olması beklenebilir (Önder vd., 2019). 
Ayhan, E. \& M. Önder (2021), "İnsan Kaynaklarının Kurumsal Performansa Etkisi:

Gençlik STK'ları Üzerine Ampirik Bir Araştırma”, Sosyoekonomi, 29(48), 443-472.

Hipotez 7: Gönüllülerin katkılarından duyulan memnuniyetin fazla olduğu STK'ların daha yüksek kurumsal performansa sahip olması beklenir.

\subsection{Profesyonel Çalışanlar}

Günümüzde sayıları ve faaliyet alanları artan STK'larda profesyonel gönüllü yönetimi yetersiz kalabilmektedir. Öncelikle, 'gönüllülüğün başarısızlığı' teorisinde de belirtildiği gibi amatör hayırseverlik kapsamında hareket eden gönüllüler karmaşık olan ve uzmanlık gerektiren konularda başarısız olabilmektedirler (Salamon, 1987). İkinci olarak, bu gönüllülerin STK'lara bağlılıkları 'gönül bağı' (Güngör, 2016) üzerinden gerçekleşmektedir. Ayrıca, bu gönüllülerin STK'lara ayıracakları vakit diğer görev ve sorumluluklarından (ev, iş, eğitim vb.) arta kalan zamana bağlı olabilmektedir. Son olarak, zorunluluk olmadığı için gönüllüler yürütmekte oldukları gönüllü faaliyetlerini tam olarak yerine getirememekte ya da bir anda bırakabilmektedirler. Bu nedenle; toplumun geniş kesimlerine ulaşmak, kurumsallaşmasını artırmak, misyonunu yerine getirmek, tanınmak, etkili ve verimli kamusal ürün ve hizmet üretmek isteyen STK'lar gönüllü çalışanlarını profesyonel, yarı zamanlı, tam zamanlı ve maaşlı çalışanlarla desteklemelidirler. Çünkü, bu çalışanlar gönüllülerden farklı olarak tüm vakitlerini STK faaliyetlerine harcayacak, uzmanlık gereken konularda (muhasebe, raporlama, yasal ve bürokratik süreçler vb.) görev alacak, sosyal sorumluluk gibi manevi hazlara ek olarak maddi anlamda da tatmin olacakları için motivasyonlarını yüksek tutacak, sözleşme süresinde görevlerini bırakamayacaklardır.

\section{Hipotez 8: Profesyonel çalışanların fazla olduğu STK'ların daha yüksek kurumsal} performansa sahip olması beklenir.

Yönetimin temel süreçlerinden biri olan insan kaynakları yönetimi, genel olarak kuruluşların amaçlarına ulaşmak için elindeki mevcut çalışanlar ile görev ve sorumlulukların yerine getirilmesiyle ilgilenir (Koç, 2016: 63). Bu nedenle, STK'lardaki çalışanların kendilerine verilen işleri etkili ve verimli bir şekilde tamamlayabilmeleri ve alanlarında yetkinlik sahibi olmaları doğrudan kurumun performansı ile de ilgilidir.

\section{Hipotez 9: Çalışanların yetkinlikleri kurumsal performansı artırır.}

\subsection{Kurumsal Eğitimler}

Nitelikli yöneticiler; finansal kaynakları etkili bir şekilde yönetebilir, kuruluşun misyonunu ve hedeflerini takip edebilir, krizlere, tehditlere ve firsatlara etkili bir şekilde cevap verebilir ve kaynak oluşturma faaliyetlerini geliştirebilirler (Önder \& Köylü, 2018). Yönetim geliştirme kuramları yönetimin kapasitesinin, çalışanların ve yöneticilerin sahip oldukları bilgi ve becerilerin sürekli bir şekilde geliştirilmesi gereği üzerinde dururlar. Özellikle, 1950'lerden sonra Mc. Gregor \& Raymond Miles'in çalışmaları sonucunda çalışanların motivasyonları, bağlılıkları, verimlilikleri, bilgi ve becerileri ve bunların geliştirilmesi ön plana çıkmıştır (Koç, 2016: 66-67). 1980’lerde stratejik insan kaynaklarının yaygınlaşması ile çalışanların nitelikleri ve yeteneklerinin kurumun ihtiyaçları doğrultusunda geliştirilmesi daha fazla önem kazanmıştır. Bunların sonucunda kurum içi eğitimler hem kamu kurumları hem de STK'lar için insan kaynakları yönetiminin temel 
aşamalarından biri haline gelmiştir (Güngör, 2016; Kocaoğlu \& Öktem, 2016). Bu eğitimler sayesinde STK'lardaki hem gönüllü hem de maaşlı çalışanlar sahip oldukları bilgi ve becerilerini geliştirebilirler. Başta kurumsallaşma olmak üzere, ilgili çalışanlara yönelik proje yazma ve yürütme, kaynak oluşturma, halkla ilişkiler ve performans yönetimi gibi alanlarda eğitimler verilmektedir. Özellikle, performans geliştirme eğitimleri sonucunda çalışanların kurumsal hedeflere ulaşılması için gereken sorumluluğu kazanacaklarından kurumsal başarı da artacaktır (Bayram, 2005: 63).

Hipotez 10: Kurumsal eğitimlerin kurumsal performansı artırması beklenir.

\section{Metodoloji}

$\mathrm{Bu}$ başlikta araştırma sorusu, hipotezler, örneklem, veri toplama, değişkenler ve bu değişkenlerin işlemselleştirilmesi, ölçekler, analiz birimi, analiz yöntemi ve modeli açıklanmaktadır.

\subsection{Araştırma Sorusu}

$\mathrm{Bu}$ çalışma, "STK'lardaki insan kaynaklarının kurumsal performans üzerinde anlaml etkisi var mıdır?” sorusuna cevap aramaktadır. Bu araştırma sorusu 1şı̆̆ında, öncelikle kurumsal kapasitenin önemli göstergelerinden olan insan kaynaklarının kurumsal performansa etkisine dair önceki kuram ve araştırmalar incelenerek hipotezler geliştirilmiştir. Bu hipotezler, anket araştırması ile elde edilen birincil düzeydeki verilere dayanarak tasarlan EKK regresyon modeli ile test edilmiştir.

\subsection{Veri Toplama}

Bağımlı ve bağımsız değişkenlerin arasındaki ilişkiyi ölçmek için gereken birincil veriler, Türkiye'nin 81 ilinden rastgele olacak şekilde seçilen 1.550 Gençlik STK Temsilcisine (başkan, yönetici, gençlik sorumlusu, gönüllü lider vb.) uygulanan ve 975 kişinin eksiksiz bir şekilde doldurarak katıldığı yarı yapılandırılmış ayrıntılı bir anket araştırmasından elde edilmiştir. Bu STK'lar, spor ve eğitim alanlarında aktif olarak faaliyet gösteren Gençlik STK'ları arasından belirlenmiştir.

\subsection{Değişkenler ve İşlemselleştirme}

Teorik ve ampirik araştırmalardan esinlenerek oluşturulan hipotezlerin testi için önceki çalışmalarda kullanılan ölçeklerden de faydalanılarak elde edilen bağımlı ve bağımsız değişkenler ve bunların işlemselleştirilmesi bu başlık altında ele alınmıştır. Araştırmaya katılan 975 Gençlik STK'sının dağılımı şu şekildedir; \%61,8'i Dernek, \%28,4'ü Vakıf, \%7'si Sendika ve \%2,8 diğer (profesyonel kuruluşlar, federasyon vb.). Anket araştırmasına katılan 975 STK temsilcisinin \%11,8'i kadın, \%88,2'si ise erkektir. Bu temsilcilerin \%68,2'si lisans mezunuyken, \%14,6'sı yüksek lisans, \%2,3'ü doktora, \%0,2'si doktora sonrası ve geriye kalan \%14,7'si lise mezuniyeti derecesine sahiptir. STK temsilcilerinin yaş durumuna bakıldığında minimum yaş 18 iken en büyük yaş 72 olmuştur. 
Yaş ortalaması ise yaklaşık olarak 37 hesaplanmıştır. Son olarak, 975 Gençlik STK'sının \%80'ini 2000 y1lı ve sonrasında kurulurken, geriye kalan \%20'si 2000 yılı öncesinde kurulmuştur. Diğer bir ifadeyle, bu STK'ların büyük çoğunluğu kurumsal yaş bakımından oldukça gençtir.

\subsubsection{Bağımlı Değişken: Kurumsal Performans}

Çalışmanın bağımlı değişkeni olan kurumsal performans, 975 Gençlik STK temsilcisine (başkan, yönetici, gençlik sorumlusu, gönüllü lider vb.) uygulanan anket araştırmasındaki şu soruya verilen cevaplardan elde edilmiştir: "Kuruluşunuzun aşağıdaki temel faaliyet alanlarındaki kurumsal performansını l'den (çok kötü) 5 'e (çok iyi) kadar olacak şekilde değerlendirir misiniz?’. Literatürden elde edilen temel faaliyet alanları şu şekildedir: 1.Tanıtım, 2.İnternet ve Teknoloji Kullanımı, 3.Yönetim teknikleri (stratejik yönetim, toplam kalite yönetimi vb.), 4.Kaynak oluşturma faaliyetleri, 5.Gönüllülük esaslı çalışma, 6.Raporlama. Bu bağımlı değişken daha önceki nicel çalışmalarda (Moynihan \& Ingraham, 2004; Moynihan \& Pveey, 2005; LeRoux \& Wright, 2010: 10) performans bilgisi elde etmek için kullanılan 5'li Likert ölçeği ile belirlenmiştir. Kurumsal performansı gösteren yeni bağımlı değişken, yukarıda ifade edilen altı temel faaliyet alanına verilen cevapların ortalamalarının alınmasıyla oluşturulmuştur. Elde edilen verilere göre en çok Orta $(\% 44,3)$ ve $\dot{I y i}(\% 37,8)$ yanıtları verilmiştir. Çok kötü, kötü ve orta yanıtları olumsuz olarak kabul edildiğinde STK temsilcilerinin \%52,8'inin kuruluşlarının kurumsal performansını düşük olarak gördüğü söylenebilir. Geriye kalan STK temsilcileri ise kurumsal performanslarını yüksek olarak değerlendirmiştir.

\subsubsection{Bağımsız Değişkenler}

Literatürde insan kaynaklarının niteliğinin ölçülmesine imkân verecek standart göstergeler bulunmamaktadır. Minzner vd. (2010: 552), The Marguerite Casey Foundation (2017), McKinsey ve Company (2001: 33-34) ile Doherty vd. (2013: 7) liderlik kapasitesini (liderlik, gönüllü eğitimi, kariyer gelişimi vb.) ve insan kaynaklarını (insan sermayesi, gönüllülük, kurumsal liderlerin yetenekleri, liderlerin sürdürülebilirliği vb.) ölçmek için bazı göstergeler kullanmışlardır. Önceki araştırmaların geliştirdiği ölçek ve modellerin temel alındığı bu çalışmada ilgili literatür irdelenerek yöneticilerin yetkinliği, gönüllüler, profesyonel çalışanlar ve kurumsal eğitimler gibi temel konuları ölçülebilir hale getirmek için farklı değişkenler geliştirilmiştir.

\section{Yöneticilerin Yetkinlikleri}

İnsan kaynaklarının önemli faktörlerinden olan yöneticilerin yetkinliği; profesyonel yöneticilik, yöneticilerin STK tecrübeleri ve eğitim düzeyleri, yönetici devrinin sıklığı ve yönetim anlayışından duyulan memnuniyet gibi değişkenler üzerinden incelenmiştir.

Profesyonel yöneticilik, maaş ödemesi profesyonellik göstergesi olarak kabul edildiği için yöneticilere ödeme yapılıp yapılmamasına göre belirlenmiştir. Bu değişkene ait veriler anket araştırmasındaki “Kuruluşunuzda yöneticilere ödeme yapıllyor mu?” sorusuna verilen 
Ayhan, E. \& M. Önder (2021), "İnsan Kaynaklarının Kurumsal Performansa Etkisi:

Gençlik STK'ları Üzerine Ampirik Bir Araştırma”, Sosyoekonomi, 29(48), 443-472.

cevaplardan elde edilmiştir. Evet/Hayır şeklinde kodlanan bu sorulardan cevabı "evet" olarak işaretlenen her birine 1 puan olacak şekilde ağırlık verilmiştir. Yapılan incelemelerde, STK'ların yaklaşık \%89'unda yöneticilere ödeme yapılmadığı görülmüştür.

Yöneticilerin STK tecrübelerine ait veriler, anket uygulanan STK temsilcilerinin gönüllü ve ücretli olarak STK'larda çalıştıkları sürelerin yıl olarak toplanmasıyla oluşturulmuştur. Yapılan incelemeler sonucunda ankete cevap veren STK temsilcilerinin yaklaşık \%50'sinin sivil toplum tecrübesinin 10 yıl ve altında kaldığı görülmüştür. Diğer taraftan, bu temsilcilerin yaklaşık \%45'i 11 yıl ile 30 yıl arasında tecrübeye sahipken, geriye kalan \%5'i ise 31 yıl ile 50 yıl arasında tecrübeye sahiptir. Yaş olarak genç olan STK temsilcilerinin tecrübesi daha yaşlı temsilcilere göre az olacağı için, bu temsilcilerin yaşları da önem arz etmektedir. Buna göre ankete katılanlar arasında minimum yaş 18 iken en büyük yaş 72 olmuştur. Yaş ortalaması ise yaklaşık olarak 37 bulunmuştur.

Yöneticilerin eğitim düzeyleri, ankette yer alan ilgili eğitim düzeyi sorusu ile elde edilmiştir. Bu kapsamda yöneticilerin eğitim düzeyleri sırasıyla kodlanarak 7 kategori elde edilmiştir: 1. İlkokul (5 yıl), 2. Ortaokul (8 yıl), 3. Lise (11 yıl), 4. Lisans (15 yıl), 5. Yüksek Lisans (17 yıl), 6. Doktora (21 yıl), 7. Doktora sonrası (23 yıl). Daha sonra eğitim düzeylerine göre literatürdeki birçok çalışmada (Ünlü vd., 2019; Bauer \& Zimmermann, 1999) olduğu gibi eğitimde geçirilen süre yıl olarak kodlanarak istatistiksel hesaplamalarda kullanılmıştır. Buna göre STK'larda İlkokul $(\% 0,3)$, Ortaokul $(\% 0,9)$, Doktora $(\% 2,3)$ ve Doktora sonrası $(\% 0,2)$ mezunlarının oranı düşükken lise $(\% 13,5)$, Yüksek Lisans $(\% 14,6)$ ve özellikle Lisans mezunlarının $(\% 68,2)$ oranı yüksektir.

Yöneticilerin devrinin sıklı̆̆l, anket araştırmasındaki “Kuruluşunuzda şu anda görev yapmakta olan başkanınızın kaçıncı başkan olduğunu belirtiniz” sorusundan faydalanılmıştır. Daha sonra kuruluşun yaşı (2018-Kuruluş Y111) toplam başkan sayısına bölünerek başkan değişiminin ortalaması elde edilmiştir. Örneğin 30 yıl önce kurulan bir kuruluştaki mevcut başkan altıncı başkan ise, ortalama beş yılda bir yönetici devri olduğu söylenebilir. Diğer taraftan elde edilen sonuçlar yine \%25'lik frekans aralıklarına bölünüp sırasıyla kodlanarak dört grup elde edilmiştir: 1) 0 - 3,00 yıl, 2) 3,01 - 5,00 y1l, 3) 5,01 - 9,00 y1l, 4) 9,01 y1l ve üzeri. Bu dört grup altında kategorize edilen veriler modele eklenmiştir. Altman'a (2014: 2-3) göre sürekli bir değişkenin kategorik hale dönüştürülmesinin bilgi ve etkinlik kaybı gibi etkileri olabilir. Ancak oluşturulan kategori sayısı 3 ya da daha fazla ve sıralı olduğunda bu kayıplar küçüktür ve verinin basitleştirilmesi ile bu kayıplar telafi edilebilmektedir. Buna göre, bir veri seti genellikle kantiller (quantile) aracılığıly 3, 4 ya da 5 gruba bölünmektedirler. Bu tarz kategorize etme yöntemi bu çalışmadaki uygun görülen diğer bağımsız değişkenlere de uygulamıştır. Elde edilen verilere göre STK'ların yaklaşık \%60'ında başkanlığın 5 yıl ve daha az sürede değiştiği söylenebilir. Başkanlık değişiminin 9 yıldan daha fazla sürede gerçekleştiği STK'ların oranı da \%15 civarındadır. Benzer bir şekilde, kuruluş yaşı incelendiğinde STK'ların \%55'i 10 yaşından daha genç olduğu görülmüştür. Diğer taraftan STK'ların \%23,2'si 11-20 yaş arasında iken geriye kalan $\% 21,1$ 'i 21 yaş ve üzerindedir. Sonuç olarak STK'ların yaklaşık \%80'inin 2000 yılı ve sonrasında kurulduğu görülmektedir. 
Yönetim anlayışından duyulan memnuniyet, anket araştırmasındaki "Kurumsal yönetim anlayışından duyduğunuz memnuniyeti 1'den (çok az) 5'e (çok yüksek) kadar olacak şekilde değerlendirir misiniz?" sorusundan elde edilmiştir: Bu soruya verilen cevaplar 1'den 5'e kadar Likert ölçeğiyle kodlanıp istatistiksel analizler yapılmıştır. Buna göre STK temsilcilerinin yaklaşık \%45'i kurumsal anlayıştan memnun değilken, geriye kalan \%55'i memnundur.

\section{Gönüllüler}

Diğer bir insan kaynakları faktörü olan gönüllülere yönelik olarak 2 farklı değişken belirlenmiştir: gönüllü çalışan sayıları ve gönüllülerin katkılarından duyulan memnuniyet. Gönüllü çalışan sayısı, gönüllü sektör kapasitesini ölçme açısından önemli bir gösterge olarak kabul edilmektedir. Gönüllü sayısı değişkenine ait veriler anket araştırmasını dolduran katılımcıların şu soruya verdikleri cevaplardan elde edilmiştir: "Lütfen kuruluşunuzun toplam gönüllü çalışan sayısını belirtiniz". Yapılan incelemeler sonucunda STK'ların yaklaşık \%50'si 10 ve altı gönüllü çalışana sahiptir. 100 ve üzeri gönüllü çalışana sahip STK'ların oranı ise \%10 civarındadır.

Gönüllülerin katkılarından duyulan memnuniyet, anket araştırmasındaki şu soruya verilen cevaplardan elde edilmiştir: "Aşağıda kuruluşunuzda görev alan gönüllüler ile ilgili olan soruları 1'den (çok kötü) 5'e (çok iyi) kadar olacak şekilde değerlendirir misiniz?”. Bu sorudaki seçenekler sırasıyla şöyledir: 1.Gönüllülerin etkinliği, 2.Gönüllülerin becerileri, 3 . Gönüllülerin sorumluluk bilinçleri ve duyarlılıkları. Bu bağımsız değişken, yukarıdaki 3 soruya verilen cevapların ortalamalarının alınmasıyla oluşturulmuştur. Buna göre STK'ların yaklaşık \%40’ında gönüllü çalışanların katkılarından duyulan memnuniyet düşük düzeydeyken, geriye kalan \%60’ında memnuniyet düzeyi yüksektir.

\section{Profesyonel Çaltşanlar}

İnsan kaynakları faktörlerinden olan profesyonel çalışanlar faktörü; tam zamanlı ve maaşlı çalışan sayısı ile iş tamamlayabilme yetkinliği üzerinden ölçülmüştür. Tam zamanlı ve maaşlı çalışan sayısı, anket araştırmasındaki şu soruya verilen cevaplardan elde edilmiştir: Lütfen kuruluşunuzun toplam maaşlı çalışan sayısını belirtiniz. Yapılan analizler sonucunda, STK'ların \%55,4'ünde hiç maaşlı çalışan bulunmazken, yaklaşık \%37,7'sinde 1-10 kişi arası, geriye kalan \%6,9'unda ise 11 kişi ve üzeri maaşlı çalışan bulunmaktadır.

Çalışanların iş tamamlayabilme yetkinlikleri değişkenine ait veriler anket araştırmasında yer alan "Lütfen kuruluşunuzun son 5 yıl içinde aşağıdaki kurum ve kuruluşlarından proje alıp almadığını belirtiniz" sorusu kapsamında elde edilmiştir: Bu kurum ve kuruluşlar sırasıyla; 1.Gençlik ve Spor Bakanlığı, 2.Ulusal Ajans, 3.Kalkınma Bakanlığı, 4.İl Özel İdaresi, 5.SODES, 6.Kalkınma Ajansı, 7.Milli Eğitim Müdürlüğü, 8.Başbakanlık Hazine Müsteşarlığı, 9.Kültür Bakanlığı, 10.İl/İlçe Belediyesi, 11.AB, 12.BM-UNDP, 13.CIDA, 14.German Marshall Fund, 15.Yabancı Ülke Elçiliği, 16. Diğer. Evet/Hayır şeklinde kodlanan bu sorulardan cevabı Evet olarak işaretlenen her birine 1 puan 
olacak şekilde ağırlık verilmiştir. Örneğin bu kurum ve kuruluşlardan 4 tanesini Evet olarak kodlayan bir STK'ya tamamlanan proje sayısı olarak 4 puan verilmiştir. Bu şekilde 975 Gençlik STK'sı için ayrı değerler bulunmuştur. Elde edilen verilere göre STK'ların yarıdan fazlası son 5 yıl içinde hiç proje tamamlamamıştır. Ayrıca 5 ve üzeri proje tamamlayan STK'ların oranı $(\% 2,3)$ çok düşüktür.

\section{Kurumsal Ĕ̈itimler}

Dördüncü insan kaynakları faktörü olan kurumsal eğitimler, kurum içi eğitim sayısı değişkeni üzerinden ölçülmüştür. $\mathrm{Bu}$ değişskene ait veriler şu anket sorusuna verilen cevaplardan elde edilmiştir: "Kuruluşunuzdaki çalışanların aşă̆ıdaki ĕgitimlerden hangilerini aldığını belirtir misiniz?”. Bu eğitimler sırasıyla; 1.Liderlik, 2.Proje eğitimi, 3.Gönüllülük, 4.Kapasite geliştirme, 5.Sivil toplum, 6.Performans yönetimi, 7.Mali yönetim, 8.Bağış toplama, 9.Konferans/Seminer, 10.Yöneticilik/İdarecilik, 11.Örgütlenme, 12.Diğer şeklindedir. Evet/Hayır şeklinde kodlanan 12 eğitimden cevabı Evet olarak işaretlenen her birine 1 puan olacak şekilde ağırlık verilmiştir. Örneğin, bu eğitimlerden 6 tanesini Evet olarak kodlayan bir STK'ya kurumsal liderlerin profesyonel yönetimi açısından 6 puan verilmiştir. Elde edilen verilere göre STK'ların \%9'unda hiç kurum içi eğitim verilmemişken sadece $\% 2,4$ 'ünde 12 eğitimin tamamı verilmiştir.

\subsection{Analiz Yöntemi ve Model}

Bağımlı ve bağımsız değişkenler arasında anlamlı bir ilişki olup olmadığı çoklu regresyon çeşidi olan ve çok sık kullanılan EKK regresyon analiz yöntemi ile tahmin edilmiştir. EKK regresyonu birçok bilimsel alanda (mühendislik, sosyal ve fen bilimleri vb.) sıkça kullanılan bir analiz yöntemidir. Bu yöntemin kullanılabilmesi için şu varsayımların karşılanması gerekmektedir: (1) katsayılara göre doğrusallık olması, (2) tüm bağımsız değişkenlerin hatalarla ilişkisiz olması, (3) hatalar arasında otokorelasyon bulunmaması, (4) hataların sabit varyanslı olması, (5) bağımsız değişkenler arasında çoklu doğrusal bağlantı sorununun bulunmaması, (6) hataların normal dağılması. EKK regresyon analiz yöntemi bu varsayımların mevcut olması halinde en iyi tahmin sonuçlarını verecektir (Tabachnick \& Fidell, 2013; Todman \& Dugard, 2007). Ayrıca, bu yöntemdeki regresyon sonuçlarına ait sonuçların kolay bir şekilde yorumlanabilmesi de bu yöntemin kullanılmasını yaygınlaştıran diğer bir tercih nedenidir. $\mathrm{Bu}$ araştırmadaki istatistiksel analiz için kullanılan regresyon modeli şu şekildedir:

$$
\begin{aligned}
& Y_{i}=\beta_{0}+\beta_{1} X_{1 i}+\cdots+\beta_{10} X_{10_{i}}+\varepsilon_{i} \\
& \mathrm{Y}: \text { kurumsal performans } \\
& \mathrm{X}^{1} \text { : profesyonel yöneticilik } \\
& \mathrm{X}^{2} \text { : yöneticilerin } \mathrm{STK} \text { tecrübeleri } \\
& \mathrm{X}^{3} \text { : yöneticilerin eğitim düzeyleri } \\
& \mathrm{X}^{4} \text { : yönetici devrinin sıklığ }
\end{aligned}
$$




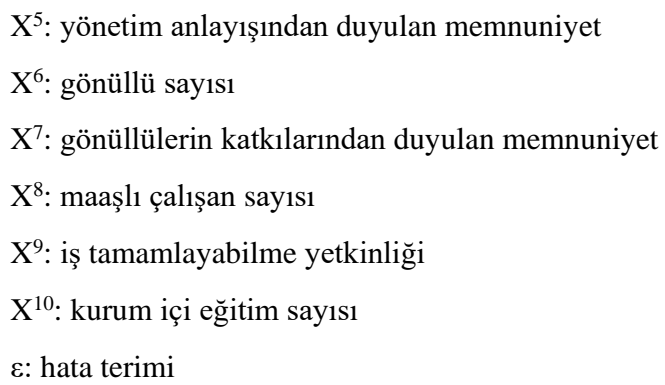

\section{Bulgular ve Değerlendirme: İnsan Kaynaklarının Kurumsal Performansa Etkisi}

Türkiye'de, STK' lara yönelik veri kaynaklarının sınırlı olmasından dolayı bu çalışma kapsamında anket araştırması yapılarak elde edilen birincil veriler analiz edilmiş ve STK'ların kurumsal performansı ile insan kaynakları faktörleri arasındaki ilişkiler istatistiksel olarak ortaya konulmuştur. Bunun için öncelikle elde edilen verilerin istatistiksel analiz için uygun olup olmadıkları çeşitli testler aracılığıyla tespit edilmiştir. Araştırma modelinde kullanılan verilerin normallik testleri birçok çalışmada kullanılan Jarque-Bera normallik testi ile yapılmıştır (Bera \& Jarque, 1981). Çarpıklık ve basıklı ölçümlerini esas alan bu test hataların normal dağılımlı olup olmadığını ölçmektedir (Brys vd., 2004). Bu testte $\mathrm{H}_{0}$ (sıfır hipotezi) hataların normal dağılımlı olduğu anlamına gelirken $\mathrm{H}_{1}$ (alternatif hipotez) ise tam tersidir. Yapılan analiz sonucunda Ki-Kare testi değeri 4,432 ve prob değeri ise 0,1091 olarak bulunmuştur. Prob $>0,05$ olduğu için $\mathrm{H}_{0}$ reddedilemez. Yani hatalar normal dağılımlı olduğu için katsayıların anlamlılıklarına ait testler ve güven aralıkları geçerlidir. Hataların farklı varyanslı (heteroskedasticity) olup olmadıkları ise Breusch-Pagan testi ile incelenmiştir. Doğrusal modellerde hataların farklı varyanslı olmaları durumunda modelin istatistiksel gücü azalır (Rosopa vd., 2013: 335). Buna göre Ki-Kare testi değeri 0,01 ve prob değeri ise 0,9184 olarak bulunmuştur. Önceki normallik testinde olduğu gibi prob değeri 0,05 'ten büyük olduğu için $\mathrm{H}_{0}$ reddedilemez.

İstatistiksel modelin başarılı olup olmadığını anlamak için otokorelasyonu da gösteren residuals denilen artıklar da incelenmiştir. Bunun için yine literatürde çokça kullanılan Durbin-Watson değerine bakılmıştır. Durbin \& Watson (1950) tarafindan önerilen bu istatistiksel hesaplama, doğrusal regresyon modelindeki hata terimlerinin seri halinde bağımsız bir şekilde hareket edip etmediklerini test eder. Bu değer yaklaşık olarak 2'ye yakın olursa artıkların seri halinde korelasyon göstermedikleri anlamına gelir (MacKinnon, 2008: 1). 1,897 olarak elde edilen Durbin-Watson değeri yaklaşık olarak 2'ye yakın olduğu için oto korelasyon sorunu bulunmamaktadır. Bir regresyon modeli için bakılması gereken diğer bir önemli değer ise çoklu doğrusallık sorunu olup olmadığını belirten VIF değerleridir. Çoklu doğrusal bağlantı problemi, bağımsız değişkenler arasında korelasyon bulunması (birbirleriyle doğrusal ilişkili olma) durumunda ortaya çıkan bir problemdir. Bu durum mevcutsa, regresyon modelindeki katsayılar ( $\beta$ 'lar) tahminlenemez. Herhangi bir korelasyon olmaması durumunda VIF değerinin 1 olması beklenir. Bu değer 
1'den büyükse eğilimin yönünü belirleyen değişkenlerin (regressors) kısmen ilişkili oldukları söylenebilir. Elde edilen değer 5 ile 10 arasındaysa yüksek korelasyon olduğu için sorun var demektir. Son olarak VIF değeri 10'un üzerindeyse ciddi bir çoklu doğrusallık olabilir (Akinwande vd., 2015: 756). Buna doğrultuda bu çalışmada kullanılan değişkenlerin VIF değerleri 1,02 ile 1,21 arasında oldukları için araştırma modelinde çoklu doğrusallık sorunu olmadığı söylenebilir.

F testi sonuçlarına bakıldığında ise prob değeri 0,05 'ten küçük olduğu için modeldeki katsayıların topluca anlamlı olduğu görülmektedir. Buna ek olarak modelin Düzeltilmiş $R^{2}$ oranının \%24,92 düzeyinde olduğu görülmektedir. Bu oran, bağımlı değişkendeki değişimin yüzde kaçının bağımsız değişkenler tarafından açıklandığını göstermektedir. Bu kapsamda, modelde kullanılan bağımsız değişkenler STK'ların kurumsal performansındaki değişimin yaklaşık \%25'ini açıklama gücüne sahip olduğu söylenebilir. Kurumsal performansa etki eden başka faktörlerin de (finansal kaynaklar, fiziki altyapı, dış paydaş ilişkileri vb.) bulunduğu göz önüne aldığında bu oran önem arz etmektedir.

\section{Tablo: 1}

\section{Çoklu Regresyon Tahmin Sonuçları}

\begin{tabular}{|c|c|c|c|c|c|}
\hline & Model & Katsayılar & p değeri & $\% 95 \mathrm{G}$ & Aralığ \\
\hline Değişkenler & Sabit & 1,5667 & $* 0,000$ & 1,2322 & 1,9012 \\
\hline \multirow{5}{*}{ Yöneticilerin Yetkinlikleri } & $\mathrm{X}^{1}$ : profesyonel yöneticilik & 0,1617 & $* * 0,021$ & 0,024 & 0,29 \\
\hline & $\mathrm{X}^{2}$ : yöneticilerin STK tecrübeleri & $-0,0017$ & 0,45 & $-0,0064$ & 0,0028 \\
\hline & $\mathrm{X}^{3}$ : yöneticilerin eğitim düzeyleri & $-0,0186$ & 0,553 & $-0,080$ & 0,043 \\
\hline & $\mathrm{X}^{4}$ : yönetici devrinin sıklığ1 & 0,0142 & 0,478 & $-0,025$ & 0,053 \\
\hline & $\mathrm{X}^{5}$ : yönetim anlayışından duyulan memnuniyet & 0,1875 & $* 0,000$ & 0,1405 & 0,2345 \\
\hline \multirow{2}{*}{ Gönüllüler } & $\mathrm{X}^{6}$ : gönüllü çalışan sayıs1 & $-0,0001$ & 0,221 & $-0,0003$ & 0,00007 \\
\hline & $\mathrm{X}^{7}$ : gönüllülerin katkılarından duyulan memnuniyet & 0,1648 & $* 0,000$ & 0,1108 & 0,2188 \\
\hline \multirow{2}{*}{ Profesyonel Çalışanlar } & $\mathrm{X}^{8}$ : maaşlı çalışan sayısı & 0,0071 & $* * 0,04$ & 0,0003 & 0,139 \\
\hline & $\mathrm{X}^{9}$ : iş tamamlayabilme yetkinliği & 0,0278 & $* * * 0,083$ & $-0,0036$ & 0,0593 \\
\hline Kurumsal Eğitimler & $\mathrm{X}^{10}:$ kurum içi eğitimler & 0,0612 & $* 0,000$ & 0,046 & 0,076 \\
\hline
\end{tabular}

Bağımlı Değişken: Kurumsal Performans, $N=973, F=33,26, R^{2}=0,2569$, Düzeltilmiş $R^{2}=0,2492$ $p<0,01 *-p<0,05 * *-p<0,1 * * *$

Tablo l'de gösterilen çoklu regresyon sonuçlarına göre altı bağımsız değişken ile bağımlı değişken arasında farklı düzeylerde $(\mathrm{p}<0,01 / \mathrm{p}<0,05 / \mathrm{p}<0,1)$ anlamlı ilişkiler bulunmuştur. Buna karşın dört bağımsız değişken ile bağımlı değişken arasında herhangi anlamlı bir ilişki gözlenmemiştir. Ayrıca, bağımsız değişkenlerin bağımlı değişkende neden oldukları değişimin düzeyi ve bu değişimin olumlu ya da olumsuz yönde olduğu da tabloda belirtilmiştir. Örneğin, bağımlı değişken ile $\mathrm{p}<0,01$ düzeyinde anlamlı bir ilişkisi olan yönetim anlayışından duyulan memnuniyet değişkeni arttıkça (katsayı 0,1875 şeklinde pozitif olduğu için) bağımlı değişken de da artmaktadır. Diğer taraftan p değeri küçüldükçe anlamlılık düzeyi de artmaktadır. Örneğin, $\mathrm{p}<0,01$ olan değerler istatistiksel olarak çok yüksek düzeyde anlamlılık olduğunu ifade ederken $\mathrm{p}<0,1$ değeri genel olarak anlamlı bir ilişki olduğunu göstermektedir. Bu kapsamda, hipotezlerin dört tanesi reddedilirken altı tanesi kabul edilmiştir. 
Ayhan, E. \& M. Önder (2021), "İnsan Kaynaklarının Kurumsal Performansa Etkisi:

Gençlik STK'ları Üzerine Ampirik Bir Araștırma”, Sosyoekonomi, 29(48), 443-472.

\subsection{Yöneticilerin Yetkinlikleri}

Profesyonel Yöneticiler: Gönüllülüğün başarısızlığı teorisine göre, uzmanlık gerektiren alanlarda gönüllü istihdam edilmesi sonucunda amatörlük nedeniyle sorunlar ortaya çıkacaktır (Salamon, 1987). Bu nedenle, gönüllü çalışanların profesyonel, maaşlı ve tam zamanlı çalışanlarla desteklenmesi gerekmektedir. Aynı şekilde, profesyonel yönetici istihdam edilmesi sonucunda kurumsal performansin da artmasi beklenmektedir. $\mathrm{Bu}$ doğrultuda, araştırmanın bulgularına göre profesyonel yöneticilik ile kurumsal performans arasında istatistiksel olarak anlamlı, doğrusal ve pozitif bir ilişki bulunduğu için Hipotez 1 kabul edilmiştir. Diğer bir ifadeyle, profesyonel yöneticilere sahip STK'larda kurumsal performans daha yüksektir.

Yöneticilerin STK Tecrübeleri: Sivil toplum alanında ücretli ya da gönüllü olarak edinilen toplam tecrübe ile kurumsal performans arasında istatistiksel olarak herhangi bir anlamlı ilişki bulunamadığ için Hipotez 2 reddedilmiştir. Literatürdeki birçok araştırmaya göre tecrübeli çalışanların ve yöneticilerin kurumun performansına ve değerine katk1 sağlayacağı düşünülmektedir (Judge vd., 1995; Nafukho vd., 2004; McDaniel vd., 1988; Humprey vd., 2009). Özellikle ampirik araştırmalarla da (Chi vd., 2009; Goll \& Rasheed, 2005; Joshi vd., 2011) bu varsayımlar desteklenmiştir. Ancak bu araştırmadaki örneklem üzerinde yapılan incelemeler sonucunda tecrübe ile kurumsal performans arasında herhangi bir ilişki tespit edilememiştir.

Yöneticilerin Eğitim Düzeyleri: Kurumsal yöneticilerin eğitim düzeyi ile kurumsal performans arasında istatistiksel olarak herhangi bir anlamlı ilişki bulunamadığı için Hipotez 3 reddedilmiştir. Personel istihdamında kişinin gerekli yeterlilik ve liyakate sahip olup olmadığına bakılması önem arz etmektedir (Koç, 2016: 69). Eğitim ise liyakat ve yeterlilik için önemli göstergelerden birisidir. Literatürdeki bazı araştırmalara göre eğitim, gelir ve yaş bakımından çeşitliliğinin yüksek olduğu yerlerde sivil toplum daha aktiftir ve buralarda insanlar nitelik ve nicelik olarak daha iyi ürün ve hizmetleri tercih ederler (Feigenbaum, 1980; Ben-Ner \& Van Hoomissen, 2007). Ayrıca, STK'lardaki gönüllü ve maaşlı çalışanlarının eğitim düzeyi arttıkça STK'ların büyüklüklerinin de arttığı gözlenmiştir (Önder, 2011). Literatürdeki bulguların aksine, bu araştırmadaki örneklem üzerinde yapılan incelemeler sonucunda eğitim ile kurumsal performans arasında herhangi bir ilişki tespit edilememiştir. Yöneticilerin yaklaşık \%70 gibi büyük bir çoğunluğunun lisans mezunu olması, eğitim grupları arasında değişimi ölçmeyi ve açıklamayı kısıtlamıştır.

Yönetici Devrinin Sıklı̆̆l: Daha önce de belirtildiği gibi, literatürdeki birçok araştırmaya göre bir kuruluşun yöneticileri uzun yıllar aynı yönetici pozisyonunda kaldıklarında, karşılaşılan sorunları genel olarak dışsal sebeplere bağlama eğiliminde olabilmektedirler. $\mathrm{Bu}$ da sorunlara yönelik çözümler geliştirilmesine, etkili kararlar alınmasına ve kurumsal performansın artırılmasına engel olabilmektedir (Chi vd., 2009; Goll \& Rasheed, 2005; Joshi vd., 2011; Schwenk, 1993). Diğer taraftan, kurumsal liderlerin çok sık değişmesi de faaliyetlerin, kurumsal hafızanın ve kurumsal kültürün sürdürülebilirliği açısından sorunlara neden olabileceği için kurumsal performansın 
azalması söz konusu olabilir. Yapılan incelemeler sonucunda, yönetici devrinin sıklığı ile kurumsal performans arasında herhangi bir anlamlı ilişki bulunamadığı için Hipotez 4 reddedilmiştir. Bu nedenle, bu araştırmanın örnekleminde yönetici devrinin sıklığını düşük ya da yüksek olmasının kurumsal performansa etkisi olmadığ 1 görülmüştür. Daha önce de belirtildiği gibi araştırmanın örneklemini oluşturan STK'ların \% 80’i 2000 yılı ve sonrasında kurulduğu için bu kuruluşlar kuruluş yaşı bakımından genç kuruluşlardır. Dolayısıyla, çok fazla yönetici değişikliği olmadığı için "yönetici devrinin sıklığı” değişkeninin kurumsal performans üzerindeki etkisi ölçülememiştir.

Yönetim Anlayışından Duyulan Memnuniyet: Önceki çalışmalarda da belirtildiği gibi dönüştürücü liderlik (Burns, 1978; Mahalinga Shiva \& Suar, 2012) ve etkileşimli liderlik (Bass \& Avolio, 1995; Kuhnert \& Levis, 1987) liderlik türlerinde çalışanların liderlerden ve kurumsal yönetim anlayışından duydukları memnuniyet kurumsal performans üzerinde olumlu bir etkiye sahiptir. Benzer bir şekilde, bu araştırmanın sonuçlarına göre de kurumsal yönetim anlayışından duyulan memnuniyet ile kurumsal performans arasında istatistiksel olarak anlamlı, doğrusal ve pozitif bir ilişki bulunduğu için Hipotez 5 kabul edilmiştir. Dolayısıyla, kurumsal yönetim anlayışından duyulan memnuniyetin fazla olduğu STK'larda kurumsal performansın da yüksek olması beklenmektedir.

\subsection{Gönüllüler}

Gönüllü Çalışan Sayısı: Bu araştırmada, gönüllü çalışan sayısı artarken kurumsal performansın da artması beklenmekteydi. Çünkü, Güngör'ün (2016) de savunduğu gibi nitelikli ve geniş bir gönüllü tabanına sahip STK'lar kısıtlı maddi imkanlarına rağmen gönüllüler aracılığıyla kamusal ürün ve hizmetler sunabilirler. Ancak yapılan analizler sonucunda, gönüllü çalışan sayısı ile kurumsal performans arasında herhangi bir anlamlı ilişki bulunamadığı için Hipotez 6 reddedilmiştir. Bu durum, gönüllüler bakımından niceliğin değil niteliğin de daha fazla önem arz ettiğini ortaya koymaktadır. Bu nedenle, STK yöneticilerinin mevcut gönüllülerin profesyonel yönetimine ve performanslarına yönelik yeni stratejiler belirlemeleri gerekmektedir.

Gönüllülerin Katkılarından Duyulan Memnuniyet: Gönüllü çalışanların katkılarından duyulan memnuniyet ile kurumsal performans arasında istatistiksel olarak anlamlı, doğrusal ve pozitif bir ilişki bulunduğu için Hipotez 7 kabul edilmiştir. Yani gönüllü çalışanların oynadıkları rolden duyulan memnuniyetin fazla olduğu STK'larda kurumsal performansın da yüksek olması beklenmektedir. Dolayısıyla, bu STK'larda daha profesyonel bir gönüllü yönetimi olduğu söylenebilir. Çünkü, gönüllülerin motivasyonlarına ve kuruma bağlılıklarına önem veren, sorumluluklarını artıran, gerekli eğitimleri veren ve ödül mekanizmalarına sahip olan STK'ların kurumsal performans açısından daha başarılı olmaları beklenebilir (Önder vd., 2019). Bu araştırmanın sonuçları da bu varsayımları desteklemektedir. Bu nedenle, gönüllü çalışanların katkılarından duyulan memnuniyetin sadece gönüllülerin bilgi ve becerilerinden değil aynı zamanda STK yöneticilerinin profesyonel gönüllü yönetiminden de kaynaklanabileceği göz önünde bulundurulması gereken önemli bir noktadır. 
Ayhan, E. \& M. Önder (2021), "İnsan Kaynaklarının Kurumsal Performansa Etkisi:

Gençlik STK'ları Üzerine Ampirik Bir Araştırma”, Sosyoekonomi, 29(48), 443-472.

\subsection{Profesyonel Çalışanlar}

Maaşlı Çalışanlar: Daha önce de belirtildiği gibi gönüllülük nedeniyle uzmanlık gerektiren alanlarda başarısız olunabileceği için (Salamon, 1987; Güngör, 2016) gönüllü çalışanların tam zamanlı profesyonel çalışanlarla desteklenmesi gerekmektedir. Benzer bir şekilde, araştırma sonuçlarına göre maaşlı çalışan sayısı ile kurumsal performans arasında istatistiksel olarak anlamlı, doğrusal ve pozitif bir ilişki bulunduğu için Hipotez 8 kabul edilmiştir. Bu açıdan, STK yöneticileri; muhasebe, raporlama, yasal ve bürokratik süreçlerin takibi gibi uzmanlık gerektiren alanlarda tam zamanlı profesyonel ve maaşlı personel istihdamına daha fazla önem verebilirler. Finansal kaynak sıkıntısı çeken STK'lar ise mevcut gönüllülerini profesyonel olarak yöneterek kuruluşun ihtiyaç duyduğu bilgi ve becerilere sahip gönüllüleri istihdam edebilirler.

Çalışanların İş Tamamlayabilme Yetkinlikleri: Mevcut çalışanların görev ve sorumluluklarını yerine getirip getirmemesi personel yönetimi için önem arz etmektedir (Koç, 2016: 63). Çünkü, çalışanların performansları arttıkça kuruluşun performansı da artacaktır. STK'ların tamamladıkları proje sayısı, kurumsal performans için önemli bir göstergedir. Çünkü çalışanları iş tamamlayabilme yeteneklerine sahip STK'lar daha fazla proje yürütebileceklerdir. $\mathrm{Bu}$ araştırmadaki örneklem üzerinde yapılan incelemeler sonucunda tamamlanan proje sayısı ile kurumsal performans arasında istatistiksel olarak anlamlı, doğrusal ve pozitif bir ilişki bulunduğu için Hipotez 9 kabul edilmiştir. Bu kapsamda, tamamlanan proje sayısı fazla olan STK'lardaki çalışanlar iş tamamlama yetkinliğine sahip oldukları için bu STK'ların performanslarının daha yüksek olduğu görülmüştür.

\subsection{Kurumsal Eğitimler}

Kurum İçi Eğitimler: Kurum içi eğitim sayısı ile kurumsal performans arasında istatistiksel olarak anlamlı, doğrusal ve pozitif bir ilişki bulunduğu için Hipotez 10 kabul edilmiştir. Kurumsal eğitim sayısının fazla olduğu STK'larda kurumsal performansın da yüksek olması beklenmektedir. Çünkü, işletmelerde olduğu gibi STK'larda da son zamanlarda kurum içi eğitimler, insan kaynaklarının temel aşamalarından biri haline gelmiştir (Güngör, 2016). Bu nedenle hem gönüllülere hem de tam zamanlı maaşlı çalışanlara yönelik olarak proje yazma ve yürütme, halkla ilişkiler, kaynak oluşturma ve performans yönetimi gibi eğitimler verilmesi önem arz etmektedir. Özellikle performans eğitimleri sayesinde çalışanların kuruma sağladıkları katkı artacaktır (Bayram, 2005: 3).

\section{Sonuç ve Politika Önerileri}

$\mathrm{Bu}$ araştırmada, özellikle 1980’lerden sonra kamu kurumları ile özel sektör kuruluşlarına yeni bir ortak olarak ortaya çıkan STK'lara dair incelemelerde bulunulmuştur. Çünkü, günümüzde STK'lar önemli bir gelişme sağlayarak kamu ve özel sektörlerin toplumsal ürün ve hizmet üretmede yetersiz ya da isteksiz oldukları alanlarda önemli bir tamamlayıcı, destekleyici veya alternatif aktör haline gelmişlerdir. Bu nedenle, kamu-özel- 
sivil toplum sektörleri arasında karşılıklı etkileşime dayalı yeni ortaklıklar gündeme gelmiştir. Ancak, çeşitli alanlarda ve bölgelerde alternatif veya tamamlayıcı kamusal ürün ve hizmet sunan bu STK'ların kapasitelerinin yeterli olup olmadığı önemli bir araştırma konusu olarak ön plana çıkmaktadır. STK'ların sahip olduğu kurumsal kapasite (finansal, insan kaynakları, fiziki ve teknolojik altyapı vb.) performanslarını da etkileyecektir. $\mathrm{Bu}$ STK'ların performanslarında meydana gelecek farklılaşmalar sonucunda ise ihtiyaç sahiplerine yönelik olarak sunulan kamusal ürün ve hizmetlerin sürdürülebilirlikleri, verimlilikleri ve erişilebilirlikleri olumsuz bir şekilde etkilenecektir. Literatürdeki birçok çalışmada, bu olumsuzlukların üstesinden gelinebilmesi için kurumsal performansta farklılaşmalara neden olan faktörler incelenerek kurumsal performansın nasıl artırılabileceği araştırılmıştır. Örneğin, STK'ların finansal kapasiteleri düşük olduğunda, faaliyetlerin ve yeni programların yürütülmesinde zorluklar yaşanabileceği çoğu araştırmada belirtilmiştir (Besel vd., 2011; Calabrese, 2013; Salamon \& Geller, 2007; Sontag-Padilla vd., 2012; Weerawardena vd., 2010). Dolayısıyla, birçok çalışmada kurumsal kapasite ile kurumsal performans arasında doğrudan bir ilişki olduğu ortaya konulmuştur (Despard, 2016: 2, De Vita \& Fleming, 2001; Light, 2004). Benzer bir şekilde, bu araştırmada kurumsal kapasitenin önemli bileşenlerinden biri olan insan kaynaklarının özgün olarak kurumsal performans üzerinde etkisi olup olmadığı araştırılmıştır. Bunun için Türkiye'nin 81 ilinden 975 Gençlik STK Temsilcisine (başkan, yönetici, gençlik sorumlusu, gönüllü lider vb.) uygulanan anket araştırması sonucunda elde edilen birincil veriler betimleyici istatistik ve EKK regresyonu yöntemleriyle incelenmiştir. Bu sonuçlara göre STK'lardaki nitelikli insan kaynakları (yönetici, profesyonel çalışan, gönüllü vb.) istihdamında; yöneticilerin yetkinlikleri, gönüllüler, profesyonel çalışanlar ve kurumsal eğitimler açısından bazı önemli sorunlar tespit edilmiştir. Araştırma bulguları doğrultusunda; STK yöneticilerine, araştırmacılara, kamu politikalarını belirleyen ve uygulayanlara, STK'ları destekleyen kamu/kamu-dışı kurum ve kuruluşlarına yönelik olarak STK'ların kurumsal performanslarının geliştirilmesi için öneriler sunulmuştur.

Profesyonel yöneticiye sahip STK'larda kurumsal performansın yüksek olduğu görüldüğü için STK'ların profesyonel yöneticilik/başkanlık sistemine geçmeleri önem arz etmektedir. Çünkü maddi kaygıları olmayan ve STK başkanlığını asli meslek olarak tam zamanlı bir şekilde yürüten başkanların kurumun performansına daha fazla katkı sunmaları beklenebilir. Bunun için sivil toplum ve kurumsal yönetim tecrübesi olan kişilerin liyakat ilkelerine göre adil ve demokratik bir şekilde belirlenmesi de önem arz etmektedir. Araştırma sonuçlarına göre yöneticilerin sivil toplum alanında edindikleri toplam deneyim, eğitim düzeyleri ve yönetici devri sıklığı gibi faktörlerin kurumsal performans üzerinde istatistiksel olarak herhangi bir anlamlı etkisi bulunamamıştır. Ancak bu araştırmada her STK'dan sadece bir kurumsal lidere yönelik anket uygulandığg için her STK'daki tüm kurumsal liderlere yönelik veri toplandığ yeniden test edilebilir. Diğer taraftan, Türkiye'deki STK'ların kurumsal kültürlerinin genel olarak başkana bağımlı bir yapıda oldukları bilinmektedir. Toplumsal değişime paralel olarak bu yapıların daha demokratik bir hale dönüşmeleri beklenebilir. Özellikle liderlik üzerine araştırma yapan araştırmacılar, STK'lardaki başkanların değişim sıklığı üzerine 
Ayhan, E. \& M. Önder (2021), "İnsan Kaynaklarının Kurumsal Performansa Etkisi:

Gençlik STK'ları Üzerine Ampirik Bir Araștırma”, Sosyoekonomi, 29(48), 443-472.

daha detaylı araştırmalar yaparak literatüre katkı sağlayabilirler. Diğer taraftan, kurumsal yönetim anlayışından duyulan memnuniyetin fazla olduğu STK'larda kurumsal performansın yüksek olduğu görülmüştür. Bu noktada, STK'ları destekleyen kamu dış1 kuruluşlar ile kamu kurumlarının STK'lara yönelik liderlik ve kurumsal yönetim teknikleri konularında eğitim sağlamaları faydalı olacaktır.

Bu araştırmada, gönüllü çalışan sayısı ile kurumsal performans arasında herhangi bir anlamlı ilişki bulunamamıştır. Her ne kadar gönüllü sayısının fazla olması olumlu olarak düşünülse de araştırma sonuçları bize niceliğin değil niteliğin daha önemli olduğunu göstermektedir. Ayrıca, daha önceki tartışmalarda belirtildiği gibi profesyonellik gerektiren durumlarda amatör yaklaşım sergilenmesi gönüllü sektör başarısızlığına sebep olabilmektedir. Bu nedenle, profesyonel maaşlı çalışan istihdam edemeyen STK yöneticilerinin mevcut gönüllülerin profesyonel yönetimine ve performanslarına yönelik yeni stratejiler belirlemeleri gerekmektedir. Dahası, halkla ilişkiler (birebir iletişim, hassas toplumsal meselelere yönelik faaliyetler vb.) ve tanıtım (sosyal medya, kamusal alanda tanıtım, sosyal kampanyalar vb.) gibi gerekli birimleri etkin hale getirerek üye sayılarını artırabilirler. Böylece, yeni üyelerle gönüllü havuzu genişletilebilir ve bu havuzdan nitelikli gönüllüler seçilerek istihdam edilebilirler. Diğer taraftan, gönüllü çalışanların katkılarından duyulan memnuniyetin fazla olduğu STK'larda kurumsal performansın daha yüksek olduğu görülmüştür. Buna göre bazı STK'lar gönüllüleri profesyonel olarak yönetirken diğerlerinin bu konuda başarısız oldukları söylenebilir. Bu kapsamda, gönüllülere yönelik gerekli kurumsal eğitimler verilmeli, sorumluluk paylaştırılmalı, maddi ve manevi ödül mekanizmaları ile gönüllülerin motivasyonları yükseltilmeli ve karar mekanizmalarındaki rolleri artırılmalıdır. Çünkü, gönüllülerin etkinliklerinin ve verimliliklerinin sadece kendi bilgi ve becerilerinden değil, STK'ların profesyonel gönüllü yönetiminden de kaynaklandığ söylenebilir.

Maaşlı çalışan sayısı ile kurumsal performans arasında istatistiksel olarak anlamlı, doğrusal ve pozitif bir ilişki bulunduğu için STK yöneticileri; muhasebe, raporlama, yasal ve bürokratik süreçlerin takibi gibi uzmanlık gerektiren alanlarda tam zamanlı profesyonel ve maaşlı personel istihdamına yönelebilirler. Diğer taraftan, maddi imkânsızlıklar nedeniyle maaşlı personel istihdam etmekte sıkıntı yaşayan STK'lar ise mevcut gönüllülerini profesyonel olarak yöneterek ihtiyaç duydukları bilgi ve beceriye sahip gönüllüleri yetiştirebilirler. Bunlara ek olarak, siyasî karar vericiler maaşlı, tam zamanlı ve profesyonel çalışanların istihdam edilebilmesi için STK'lara kamusal destek (vergi, prim ve stopaj muafiyeti vb.) verebilir, yasal güncellemeler yapabilir ve sivil toplumda elde edilebilecek kariyer imkânlarını cazip hale getirebilirler. Dahası, kamu kurumlarında çalışmak için başvuruda bulunanlardan tercihen sivil toplum tecrübesi olması istenebilir. Böylece STK'ların ihtiyaç duyduğu nitelikli insan kaynağı sağlanacak ve sivil toplumda kariyer yapma cazip hale gelecektir. Son olarak, bu araştırmada çalışanların iş tamamlayabilme yetkinlikleri, STK'ların tamamladıkları proje sayısı üzerinden ölçülmüştür. Çünkü çalışanları iş tamamlayabilme yeteneklerine sahip STK'lar daha fazla proje tamamlayabileceklerdir. Araştırma sonuçlarına göre, tamamlanan proje sayısı ile kurumsal performans arasında istatistiksel olarak anlamlı, doğrusal ve pozitif bir ilişki bulunmaktadır. 
Bu anlamda, STK yöneticileri personel yönetimi ile sadece proje yazma ve yürütme alanında değil diğer faaliyet alanlarında da çalışanların iş tamamlayabilme yetkinliklerini artıracak stratejik planlar yapmalıdırlar.

Kurum içi eğitim sayısı yüksek olan STK'larda kurumsal performans daha yüksek olduğu için STK yöneticileri bu anlamda dışarıdan uzman desteği alarak eğitimlerin sayısını artırmalıdırlar. Buna ek olarak STK'ları destekleyen kamu kurumları ve kamu dışı kuruluşlar da bu anlamda STK çalışanlarına yönelik proje yazma ve yürütme, halkla ilişkiler, kaynak oluşturma ve performans yönetimi gibi ücretsiz eğitimler düzenleyebilirler.

\section{Kaynaklar}

Akatay, A. (2008), "Gönüllü Kuruluşların İnsan Kaynakları Sorunlarına Eğitsel Bir Çözüm”, Çanakkale Onsekiz Mart Üniversitesi Girişimcilik ve Kalkınma Dergisi, 3(1), 115-137.

Akinwande, M.O. \& H.G. Dikko \& A. Samson (2015), "Variance Inflation Factor: As A Condition for the Inclusion of Suppressor Variable(s) in Regression Analysis", Open Journal of Statistics, 5, 754-767.

Altman, D.G. (2014), Categorizing Continuous Variables, Wiley StatsRef: Statistics Reference Online.

Anheier, H.K. (2005), Nonprofit Organizations: Theory, Management, Policy, London and New York: Routledge.

Ayhan, E. \& M. Önder (2017), "Yeni Kamu Hizmeti Yaklaşımı: Yönetişime Açılan Bir Kapı”, Gazi Iktisat ve İsletme Dergisi, 3(2), 19-48.

Ayhan, E. (2019), “An Empirical Study for the Financial Situation of Youth CSOs in TRB1 Region of Turkey”, Bingöl Üniversitesi İktisadi ve İdari Bilimler Dergisi, 3(2), 39-72.

Barney, J.B. \& W.S. Hesterly (2012), Strategic Management and Competitive Advantage (4. Bask1), MA: Pearson, Boston.

Bass, B.M. \& B.J. Avolio (1995), The Multifactor Leadership Questionnaire, Palo Alto: Mind Garden.

Bauer, T. \& K.F. Zimmermann (1999), "Overtime Work and Overtime Compensation in Germany”, Scottish Journal of Political Economy, 46(4), 419-436.

Bayram, L. (2005), “Geleneksel Performans Değerlendirme Yöntemlerine Yeni Bir Alternatif: 360 Derece Performans Değerlendirme", Sayıştay Dergisi, 62, 47-65.

Ben-Ner, A. \& T. Van Hoomissen (2007), "Nonprofit Organizations in the Mixed Economy: A Demand and Supply Analysis", Annals of Public and Cooperative Economics, 62(4), 519-550.

Bera, A. \& C. Jarque (1981), "Efficient tests for normality, heteroskedasticity and serial independence of regression, residuals: Monte Carlo Evidence", Economics Letters, 7 , 313-318.

Besel, K. \& C.L. Williams \& J. Klak (2011), "Nonprofit Sustainability during Times of Uncertainty", Nonprofit Management and Leadership, 22, 53-65.

Bibu, N. \& M. Lisetchi (2011), "Particularities of the Strategy Approach within Nongovernmental Organizations: A Literature Review", Managerial Challenges of the Contemporary Society, 2, 23-27. 
Bilgin, K.U. (2015), “Kamu Personel Yönetiminde Ölçüt ve Gösterge Odaklı Performans Yönetimi”, Strategic Public Management Journal, 1(1), 24-39.

Bilgin, Y. \& G.D. Bilgin \& I. Kilinc (2017), "Strategic Leadership in Civil Society Organizations: A Research on Turkish Charities Performing International Operations", VOLUNTAS, 28, 839-863.

Boal, K.B. \& R. Hooijberg (2000), "Strategic Leadership Research: Moving On”, Leadership Quarterly, 11(4), 515-549.

Brys, G. \& M. Hubert \& A. Struyf (2004), “A Roubustification of the Jarque-Bera Test of Normality”, J. Antoch (ed.), Proceedings in Computational Statistics, Heidelberg: Springer-Verlag, 753-760.

Burns, M.G. (1978), Leadership, New York: Harper-Row.

Calabrese, T. (2013), "Running on Empty: The Operating Reserves of U.S. Nonprofit Organizations", Nonprofit Management and Leadership, 23, 281-302.

Carman, J.G. (2007), "Evaluation Practice Among Community-Based Organizations: Research into the Reality", American Journal of Evaluation, 28(1), 60-75.

Carter, S.M. \& C.R. Greer (2013), "Strategic Leadership: Values, Styles, And Organizational Performance", Journal of Leadership \& Organizational Studies, 20(20), 1-19.

Chi, N.W. \& Y.M. Huang \& S.C. Lin (2009), “A Double-Edged Sword? Exploring the Curvilinear Relationship Between Organizational Tenure Diversity and Team Innovation: The Moderating Role of Team-Oriented HR Practices", Group and Organization Management, 34, 698-726.

Christensen, R.K. \& B. Gazley (2008), "Capacity for Public Administration: Analysis of Meaning and Measurement", Public Administration and Development, 28, 265-279.

Connolly, J.M. (2018), "Can Managerial Turnover Be A Good Thing? The Impact Of City Manager Change On Local Fiscal Outcomes", Public Administration Review, 78(3), 338-349.

Cooter, R. \& T. Ulen (2000), Law and Economics, Boston: Addison Wesley Longman.

Coşkun, A. (2006), "STK'ların Stratejik Performans Yönetiminde Yeni Bir Yaklaşım: Performans Karnesi”, Sivil Toplum, 4(15), 103-117.

Çaha, Ö. \& A. Çaylak (2013), TRA2 Bölgesi Sivil Toplum Kuruluşları Profili, Kars: SERKA Kalkınma Ajansı, <https://www.serka.gov.tr/assets/upload/dosyalar/55ba930f4b08681a4f8f5ad8b315b743. pdf>, 09.04.2020.

Çaha, Ö. \& M.E. Köktaş \& A. Çaylak \& M. Önder \& A. Akın \& H. Kapu (2018), TRA2 Bölgesi Gençlik Araştırması. Kalkınma Bakanlığı, SERHAT Kalkınma Ajansı (ISBN 978-60568045-2-6), Kars: SERKA Yayınları.

De Vita, C.J. \& C. Fleming (eds.) (2001), Building Capacity in Nonprofit Organizations, Washington, DC: The Urban Institute, <http://research.urban.org/UploadedPDF/building_capacity.PDF>, 09.06.2020.

Despard, M.R. (2016), “Can Nonprofit Capacity Be Measured?”, NVSQ, 46(3), 1-20.

Dinwoodie, D.L. \& L. Quinn \& J.B. McGuire (2014), Bridging The Strategy/Performance Gap: How Leadership Strategy Drives Business Results, Center for Creative Leadership, <http://insights.ccl.org/wp-content/uploads/2015/04/BridgingTheStrategy.pdf>, 09.04.2020. 
Doherty, A. \& K. Misener \& G. Cuskelly (2013), "Toward A Multidimensional Framework of Capacity in Community Sport Clubs", NVSQ, 43(2), 1-19.

Doherty, K.M. \& D.E. Lewis \& S. Limbocker (2019), "Executive Control And Turnover In The Senior Executive Service", Journal of Public Administration Research and Theory, 29(2), 159-174.

Durbin, J. \& G. Watson (1950), “Testing For Serial Correlation In Least Squares Regression I", Biometrika, 37, 409-428.

Eisinger, P. (2002), "Organizational Capacity and Organizational Effectiveness Among Street Level Food Assistance Programs”, NVSQ, 31(1), 115-130.

Ekmekçi, Ö.T. \& S. Güney \& M.K. Öktem (2019), Örgütsel Stres Faktörlerinin Algılanan İş Stresi Üzerindeki Etkisinde Dönüşümsel Liderliğin Düzenleyici Rolü”, 2-3 Kasım, Süleyman Demirel Üniversitesi, 6. Örgütsel Davranış Bilimleri Kongresi Bildiriler Kitabı, 591-601.

Feigenbaum, S. (1980), "The Case of Income Redistribution: A Theory of Government and Private Provision of Collective Goods", Public Finance Quarterly, 8(1), 3-22.

Fine, T. \& L. Snyder (1999), "What Is The Difference Between Performance And Benchmarking?", Public Management, 81(1), 24-25.

Fowler, A. (2000), The Virtuous Spiral: A Guide to Sustainability for NGOs in International Development, London: Earthscan.

Frederickson, D.G. \& H.G. Frederickson (2007), Measuring The Performance Of The Hollow State, Washington, DC: Georgetown University Press.

Froelich, K.A. (1999), "Diversification of Revenue Strategies: Evolving Resource Dependence In Nonprofit Organizations", NVSQ, 28(3), 246-268.

Garton, J. (2009), The Regulation of Organised Civil Society, Oxford: Hart Publishing.

Goel, S.L. \& R. Kumar (2005), Administration And Management of NGOs: Text And Cases, New Delhi: Deep and Deep Publications.

Goll, I. \& A.A. Rasheed (2005), “The Relationships Between Top Management Demographic Characteristics, Rational Decision Making, Environmental Munificence, and Firm Performance", Organization Science, 26, 999-1023.

Göçoğlu, Ü.V. \& İ.D. Kurt \& M.K. Öktem (2019), "İdari Reformun Yüz Y1lı: Türk Kamu Yönetimi Reformlarının Karar Verme Yaklaşımları Çerçevesinde Değerlendirilmesi”, Ombudsman Akademik, 5(10), 39-83.

Gronbjerg, K.A. (1993), Understanding Non-Profit Funding: Managing Revenues in Social Services and Community Development Organizations, San Francisco: Jossey-Bass.

Güngör, F. (2016), “Gönüllü Yönetiminin Önemli Bir Aşaması Olarak Performans Değerlendirme”, Strategic Public Management Journal, 4, 21-48.

Hackler, D. \& G.D. Saxton (2007), "The Strategic Use of Information Technology by Nonprofit Organizations: Increasing Capacity and Untapped Potential”, Public Administration Review, 67(3), 474-487.

Hansmann, H. (1987), "Economic Theories of Nonprofit Organizations”, içinde: W.W. Powell (ed.), The Nonprofit Sector: A Research Handbook (1. edition), New Haven: Yale University Press, 27-42.

Herman, R.D. \& D.O. Renz (2008), “Advancing Nonprofit Organizational Effectiveness Research and Theory: Nine Theses", Nonprofit Management and Leadership, 18(4), 399-415. 
Hill, C.W.L. \& G.R. Jones (2008), Strategic Management: An Integrated Approach (8. edition), MA: Houghton-Mifflin, Boston.

Hillman, A.J. \& M.C. Withers \& B.J. Collins (2009), "Resource Dependence Theory: A Review", Journal of Management, 35(6), 1404-1427.

Honadle, B.W. (1981), "A Capacity Building Framework: A Search for Concept and Purpose", Public Administration Review, 41, 575-580.

Humphrey, S.E. \& F.P. Morgeson \& M.J. Mannor (2009), "Developing A Theory of Strategic Core of Teams: A Role Composition Model of Team Performance", Journal of Applied Psychology, 94, 48-61.

James, E. \& S. Rose-Ackerman (1986), The Nonprofit Enterprise in Market Economies, New York: Harwood Academic Publishers.

Joshi, A. \& H. Liao \& H. Roh (2011), "Bridging Domains in Workplace Demography Research: A Review and Reconceptualization", Journal of Management, 37, 521-552.

Judge, T.A. \& D.M. Cable \& J.W. Boudreau \& R.D. Bretz (1995), “An Empirical Investigation of The Predictors of Executive Career Success", Personnel Psychology, 48, 485-519.

Kocaoğlu, U.B. \& M.K. Öktem (2016), "Administrative Capacity for Municipalities: Comparison of Sample Case Municipalities of Central Anatolia Region and the State of Arizona", Akademik Yaklaşımlar Dergisi, 7(2), 69-85.

Koç, T. (2016), Yönetim Bilimi ve Türkiye’de Yönetsel Kurumlar, Adana: Karahan Kitabevi.

Koçel, T. (2001), İşletme Yöneticiliği (8. edition), İstanbul: Beta Yayınları.

Kuhnert, K.W. \& P. Lewis (1987), "Transactional And Transformational Leadership: A Constructive/Developmental Analysis”, Academy of Management Review, 12(4), 648657.

Lear, L.W. (2012), The Relationship Between Strategic Leadership And Strategic Alignment In High Performing Companies In South Africa, South African Republic: University of South Africa, Graduate School of Business Leadership.

LeRoux, K. \& N.S. Wright (2010), "Does Performance Measurement Improve Strategic Decision Making? Findings From a National Survey of Nonprofit Social Service Agencies", NVSQ, 39(4):571-587.

Levitt, T. (1973), The Third Sector: New Tactics for a Responsive Society, New York, AMACOM.

Light, P.C. (2004), Sustaining Nonprofit Performance: The Case for Capacity Building and the Evidence to Support It, Washington: Brookings Institution Press.

MacKinnon, J.G. (2008), "Durbin-Watson Statistics", The New Palgrave Dictionary of Economics, $1-3$.

Mahalinga-Shiva, M.S.A. \& D. Suar (2012), "Transformational Leadership, Organizational Culture, Organizational Effectiveness, and Programme Outcomes in Non-Governmental Organizations", VOLUNTAS, 23, 684-710.

McDaniel, M.A. \& F.L. Schmidt \& J.E. Hunter (1988), "Job Correlates of Job Performance", Journal of Applied Psychology, 73, 327-330.

McKinsey and Company (2001), Effective Capacity Building in Nonprofit Organizations (Report to Venture Philanthropy Partners), <https://www.neh.gov/files/divisions/fedstate/vppartnersfull_rpt_1.pdf>, 09.06.2020. 
Millesen, J.L. \& J.G. Carman \& A.L. Bies (2010), "Why Engage? Understanding the Incentive to Build Nonprofit Capacity", Nonprofit Management and Leadership, 21(1), 5-20.

Minzner, A. \& J. Jastrzab \& J. Klerman \& C. Markovitz \& J. Williams \& B. Fink \& S. Cynthia \& C. Matthew \& B. Tia (2010), Improving Capacity Among Nonprofits: Impact Study of The Compassion Capital Fund Demonstration Program, <https://www.acf.hhs.gov/sites/default/files/opre/ccf_impact_rprt_final.pdf>, 02.06.2020.

Mitchell, G.E. (2014), "Strategic Responses To Resource Dependence Among Transnational NGOs Registered in the United States", VOLUNTAS, 25, 67-91.

Morley, E. \& E. Vinson \& H. Hatry (2001), Outcome Measurement in Nonprofit Organizations: Current Practices And Recommendations, Washington, DC: Urban Institute.

Moynihan, D.P. \& P. Ingraham (2004), "Integrative Leadership In The Public Sector: A Model Of Performance Information Use", Administration and Society, 36, 427-453.

Moynihan, D.P. \& S.K. Pveey (2005), "Testing How Management Matters in an Era of Government By Performance Management", Journal of Public Administration Research and Theory, 15(3), 421-439.

Moynihan, D.P. (2005), “Goal-Based Learning and The Future of Performance Management”, Public Administration Review, 65, 203-216.

Myers, M.B. \& D.A. Griffith \& P.J. Daugherty \& R.F. Lusch (2004), "Maximizing the Human Capital Equation in Logistics: Education, Experience, And Skills", Journal of Business Logistics, 25, 211-232.

Nafukho, F.M. \& N. Hairston \& K. Brooks (2004), "Human Capital Theory: Implications for Human Resource Development", Human Resource Development International, 7, 545-551.

Olson, M. (1971), The Logic of Collective Action: Public Goods And the Theory of Groups, Cambridge \& London: Harvard University Press.

Oster, S.M. (1995), Strategic Management for Nonprofit Organizations: Theory and Cases, New York: Oxford University Press.

Öktem, M.K. \& L. Çiftçi (2019), "Kamu Yönetiminde Yeni Yaklaşımlar ve Türk Eğitim Sistemine Yansımaları", 12-22 Haziran, Ankara Üniversitesi, EJERCongress Bildiri Kitabı, 25462558.

Önder, M. \& A. Akın \& E. Ayhan (2019), Türkiye Gençlik STK'ları Profili, Gençlik ve Spor Bakanlığı, ISBN, 978-605-4858-44-6. Ankara: Gençlik ve Spor Bakanlığı.

Önder, M. \& E. Ayhan (2020), "Financial Vulnerability of NGOs in Southeast Anatolia and Mediterranean Regions", Eurasian Economic Perspectives, 12(1), 37-53.

Önder, M. \& M. Köylü (2018), “ABD Yerel Yönetimlerinde Profesyonel Kent Yöneticiliği Modeli Yayılıyor mu?”, Çăgdaş Yerel Yönetimler Dergisi, 27(1), 77-112.

Önder, M. (1997), “Toplam Kalite Yönetimi, Kamu Sektöründe Uygulanması ve Karşılaşılan Sorunlar", Türk Idare Dergisi, 69(416), 117-136.

Önder, M. (2006), "How Local Conditions Affect the Existence and Capacity of the Nonprofit Sector: A Test of Competing Theories", PhD Dissertation, Florida State University. <http://purl.flvc.org/fsu/fd/FSU_migr_etd-2290>, 30.01.2021.

Önder, M. (2011), “A Preliminary Cross National Test of Competing Theories of Nonprofits: Does Culture Matter?”, The International Review of Public Administration, 16(1), 71-90. 
Ayhan, E. \& M. Önder (2021), "İnsan Kaynaklarının Kurumsal Performansa Etkisi:

Gençlik STK'ları Üzerine Ampirik Bir Araştırma”, Sosyoekonomi, 29(48), 443-472.

Önder, M. (2012), “Third Sector Research”, International Review of Public Administration, 17(1), 195-199.

Önder, T. (2019), “Globalleşme ve Ulus Devlet”, Iletişim Kuram ve Araştırma Dergisi, 49, 207-220.

Özer, M.A. (2006), “Yönetişim Üzerine Notlar”, Sayıştay Dergisi, 63, 59-89.

Özer, M.A. (2009), "Performans Yönetimi Uygulamalarında Performansın Ölçümü ve Değerlendirilmesi”, Sayıştay Dergisi, 73, 3-29.

Özgür, H. \& G. Aydın (2020), “Türk Kamu Sektörü Bireysel ve Kurumsal Performans

Değerlendirme Politikasının Uygulama Aşamasının Analizi: 1965-2018”, Kaтu Yönetimi ve Politikaları Dergisi, 1(3), 6-35.

Pfeffer, J. \& G.R. Salancik (1978), The External Control of Organizations: A Resource Dependence Perspective, New York: Harper and Row.

Rosopa, P.J. \& M.M. Schaffer \& A.N. Schroeder (2013), "Managing Heteroscedasticity in General Linear Models", Psychological Methods, 18(3), 335-351.

Salamon, L.M. \& H.K. Anheier \& R. List \& S.W. Sokolowski \& S. Toepler (1999), Global Civil Society: Dimensions of the Nonprofit Sector, Baltimore: The John Hopkins Center for Civil Society Studies.

Salamon, L.M. \& S.L. Geller (2007), Nonprofit Fiscal Trends and Challenges (No. 6), Baltimore, MD: Johns Hopkins University, Center for Civil Society Studies, Institute for Policy Studies, <http://ccss.jhu.edu/wpcontent/uploads/downloads/2011/09/LP_Communique6_2007.pdf>, 16.02.2020.

Salamon, L.M. (1987), “Of Market Failure, Voluntary Failure, and Third-Party Government: Toward a Theory of Government-Nonprofit Relations in the Modern Welfare State", NVSQ, 16(1-2), 29-49.

Saruhan, Ş.C. \& M.L. Yıldız (2017), Çağdaş Yönetim Bilimi (3. Baskı), İstanbul: Beta Yayınları.

Schwenk, C. (1993), "Management Tenure and Explanations for Success and Failure", Omega, 21(4), 449-456.

Shrivastava, P. \& S.A. Nachman (1989), “Strategic Leadership Patterns”, Strategic Management Journal, 10, 51-66.

Smith, G.S. (1988), "Performance Evaluation For Nonprofits: A Tested Method For Judging Your Organization's Performance", Nonprofit World, 6(1), 24-25.

Sontag-Padilla, L.M. \& L. Staplefoote \& K.G. Morganti (2012), "Financial Sustainability for Nonprofit Organizations: A Review of The Literature", Research Report, sponsored by the YMCA of Greater Pittsburgh, <https://www.rve.org/content/dam/rve/pubs/research_reports/RR100/RR121/RVE_RR12 1.pdf >, 16.02.2020.

Steffens, N.K. \& M. Shemla \& J. Wegge \& S. Diestel (2014), "Organizational Tenure and Employee Performance: A Multilevel Analysis", Group and Organization Management, 39(6), 664690.

Steinberg, R. (2006), "Economic Theories of Nonprofit Organizations", içinde: W.W. Powell \& R. Steinberg (eds), The Nonprofit Sector: A Research Handbook (2. edition), New Haven: Yale University Press, 117-139.

Tabachnick, B.G. \& L.S. Fidell (2013), Using Multivariate Statistics (6. edition), Boston: Pearson. 
The Marguerite Casey Foundation (2017), Organizational Capacity Assessment Tool, <https://caseygrants.org/resources/org-capacity-assessment/>, 09.06.2020.

Tiyek, R. (2013), "Sivil Toplum Kuruluşlarında Kurumsal Performansın Ölçülmesi: Bir Model Önerisi”, Çalışma İlişskileri Dergisi, 4(1), 125-134.

Todman, J.B. \& P. Dugard (2007), Approaching Multivariate Analysis: An Introduction for Psychology, New York: Psychology Press.

Tuckman, H.P. \& C.F. Chang (1991), “A Methodology for Measuring the Financial Vulnerability of Charitable Nonprofit Organizations", VOLUNTAS, 20(4), 445-460.

Tuckman, H.P. (1998), “Competition, Commercialization, and the Evolution of Nonprofit Organizational Structures", içinde: B. Weisbrod (ed), To Profit or Not to Profit: The Commercial Transformation of the Nonprofit Sector, Cambridge: CUP, 25-46.

Ünlü, M. \& A. Selvi \& Ş. Üçdoğruk-Birecikli (2019), “Türkiye'de Özel Sektörde Fazla Mesai: Tobit Modelle İncelenmesi”, İzmir İktisat Dergisi, 34(1), 125-135.

Wayne, S.J. \& R.C. Liden \& M.L. Kraimer \& I.K. Graf (1999), “The Role of Human Capital, Motivation and Supervisor Sponsorship in Predicting Career Success", Journal of Organizational Behavior, 20, 577-595.

Weerawardena, J. \& R.E. Mcdonald \& G.S. Mort (2010), "Sustainability of Nonprofit Organizations: An Empirical Investigation", Journal of World Business, 45, 346-356.

Weisbrod, B.A. (1975), “Toward a Theory Of The Voluntary Nonprofit Sector In A Three-Sector Economy", içinde: E. Phelps (ed.), Altruism, Morality And Economic Theory, New York: Russell Sage Foundation, 171-196.

Wholey, J.S. (1999), “Performance-Based Management: Responding To The Challenges”, Public Performance and Management Review, 22, 288-307.

Yıldırım, K. \& M. Önder (2019), "Collaborative Role of Metropolitan Municipalities in Local Climate Protection Governance Strategies: The Case of Turkish Metropolitan Cities", Journal of Environmental Assessment Policy and Management, 21(2). 